\title{
New experimental surgical techniques for paediatric bladder augmentation and continent cutaneous diversion
}

Raimondo Maximilian Cervellione M.D.

Ph. D. Thesis

Institute of Surgical Research

University of Szeged 


\section{New experimental surgical techniques for paediatric bladder augmentation and continent cutaneous diversion}

Raimondo Maximilian Cervellione M.D.

Ph. D. Thesis

Supervisor: Tamas Cserni M.D.,Ph.D.

Institute of Surgical Research

Multidisciplinary Doctoral School

Faculty of Medicine of University of Szeged 


\section{The list of publications on which the thesis was based on:}

I, Cervellione RM, Bianchi A, Fishwick J, Gaskell SL, Dickson AP.

Salvage procedures to achieve continence after failed bladder exstrophy repair.

J Urol 2008; 179 :304-6 IF 3.952

II, Cervellione RM, Varga G, Hajnal D, Erces D, Kaszaki J, Harwood R, Rakoczy $\mathrm{G}$, Cserni T. Intestinal Intramural Vascular Anastomoses.

J Invest Surg 2016;29:51-6. IF: 1.000

III, Cserni T, Cervellione RM, Hajnal D, Varga G, Kubiak R, Rakoczy G, Kaszaki J, Boros M, Goyal A, Dickson A. Alternative ileal flap for bladder augmentation if mesentery is short.

J Pediatr Urol 2015;11:64. IF: 1.170

IV, Cervellione RM, Hajnal D Varga G, Erces D, Kaszaki J, Rakoczy G, Cserni T. Mucosectomy impairs ileal microcirculation and results in flap contraction after experimental ileocystoplasty.

J Pediatr Urol 2017;13:81.e1-81.e5. IF: 1.170

V, Cervellione RM, Hajnal D, Varga G, Rakoczy G, Kubiak R, Kaszaki J, Boros M, Harwood R, Dickson AP, Cserni T. New alternative Mitrofanoff channel based on spiral intestinal lengthening and tailoring.

J Pediatr Urol. $2015 ; 11: 131 . e 1-5$. IF: 1.170

Total IF: 8,462

Other publications related to the topic

I, Dickson AP, Khalil BA, Cervellione RM. Rectus sheath tunnels for continent stomas.

Pediatr Surg Int 2008;24:283-6.

II, Cervellione RM, Kyriazis I, Dickson AP. Construction of a natural looking inverted umbilicus for bladder exstrophy.

J Urol 2008;180:1869-72.

III, Ferrara F, Dickson AP, Fishwick J, Vashisht R, Khan T, Cervellione RM.

Delayed exstrophy repair (DER) does not compromise initial bladder development.

J Pediatr Urol 2014;10:506-10.

IV, Cervellione RM. Re: Use of cutaneous flap for continent cystostomy (daoud technique). Editorial comment.

J Urol 2010;184:1121.

V, Baradaran N, Stec A, Wang MH, Cervellione RM, Luskin J, Gearhart JP. Urinary diversion in early childhood: indications and outcomes in the exstrophy patients.

Urology 2012;80:191-5. 


\title{
CONTENTS
}

\section{LIST OF ABBREVIATIONS}

\section{INTRODUCTION}

\author{
1.1. Indication of bladder augmentation and continent cutaneous diversion in \\ children \\ 1.2. Different types of bladder augmentation \\ 1.3. Clam ileocystoplasty \\ 1.3.1. Concerns of ileocystoplasty \\ 1.3.1.1. Short mesentery \\ 1.3.1.2. Mucus production \\ 1.3.1.3. Metabolic issues \\ 1.3.1.4. Malignancy \\ 1.3.1.5. Flap contraction after augmentation with mucosectomised intestinal flaps \\ 1.4. Continent urinary stomas in children \\ 1.4.1. Mitrofanoff principle \\ 1.4.2. Monti procedure \\ 1.4.3. Long channels: double Monti procedure, Casale technique \\ 1.4.3.1. Concerns of Long channels (Double Monti, Casale technique) \\ 1.5. Intestinal intramural microcirculation \\ 1.6. Imaging of the microcirculation
}

\section{MAIN GOALS}

2.1. I. Assess the clinical importance and efficacy of the bladder augmentation and continent cutaneous diversion in patients after failed bladder exstropy repair

2.2. II. Study the intramural microcirculation of the ileal flap used for augmentation

2.3. III. To develop new technique for augmentation if mesentery short

2.4. IV. Effect of mucosectomy on flap microcirculation and flap contraction

2.5. V. To test new concept to create long and straight continent urinary stomas

\section{MATERAIL AND METHODS}

3.1. Patients and methods in Study I.

3.2.1. Research animals, anaesthesia

3.2.2. Measurement of the microcirculation

3.2.3. Surgical preparations and experimental protocol in Study II.

3.2.4. Surgical preparations and experimental protocol in Study III.

3.2.5. Surgical preparations and experimental protocol in Study IV.

3.2.6. Surgical preparations and experimental protocol in Study V.

3.2.7. Statistical analysis

\section{RESULTS}

4.1. Clinical importance and efficacy of the bladder augmentation and continent cutaneous diversion

4.2. Intramural microcirculation of the ileal flap

4.3. New technique for augmentation if mesentery short 
4.4. Effect of mucosectomy on flap microcirculation and flap contraction

4.5. New concept to create long and straight continent urinary stomas

\section{DISCUSSION}

5.1. Clinical importance and efficacy of the bladder augmentation and continent cutaneous diversion

5.2. Intramural microcirculation of the ileal flap

5.3. Effect of mucosectomy on flap microcirculation and flap contraction

5.4. New technique for augmentation if mesentery short

5.5. New concept to create long and straight continent urinary stomas

5.6. Summary of the new results and conclusions

6. LIST OF REFERENCE

7. SUMMARY

8. MAGYAR NYELVÜ ÖSSZEFOGLALÓ

9. AKNOWLEDGEMENT

10. APPENDIX 


\section{LIST OF ABBREVIATIONS}

BA- bladder augmentation

BNR- bladder neck repair

CCD- cutaneous continent diversion

CPR-capillary perfusion rate

ESD- endoscopic submucosal dissection

ICC-intermittent clean catheterising

IDF-incident dark filed imaging

LDPI- laser Doppler perfusion Imaging

LSPCI-laser speckle contrast imaging

MACE -Malone antegrade continence enema

OPS- orthogonal polarization spectral imaging

PR-perfusion rate

RBC- red blood cell

RBCV-red blood cell velocity

SDF-sidestream dark field imaging

SILT- spiral intestinal lengthening and tailoring

VR-vasa recta 


\section{INTRODUCTION}

\subsection{Indication of bladder augmentation and continent cutaneous diversion in paediatric reconstructive urology}

Patients with failed bladder exstrophy, cloacal exstrophy repair and failed medical management of severe neurogenic bladder dysfunction are the most common candidates for bladder augmentation and continent cutaneous urinary diversion. Decreased bladder capacity, high intravesical pressure and low compliance are the main indications for bladder augmentation. The intravesical use of Botolinum toxin injection has significantly lowered the number of bladder augmentation required due to overactive detrusor function in neurogenic bladder, but bladder augmentation remains the optimal option when bladder capacity is not adequate and the intravesical pressure remains high (1).

Continent cutaneous diversion is necessary when the patient is not able to empty the bladder properly with intermittent clean catheterising (ICC). If the bladder capacity and compliance are satisfactory it can be done alone. However, if low capacity and compliance requires augmentation diversion is performed along the augmentation procedure (1).

\subsection{Different types of bladder augmentations}

Surgically the bladder capacity can be augmented in different ways. In autoaugmentation the detrusor muscle is incised and stripped from the bladder mucosa. This allows the bladder mucosa to bulge out like a diverticulum. Unfortunately autoaugmentation does not provide enough additional capacity. So it can be used only for good capacity bladder with poor compliance to block uninhibited detrusor contraction. In long term fibrosis and contraction of the diverticulum occurs (2).

If dilated ureter attached to a non-functioning hydronephrotic kidney is available augmentation with the dilated ureter may be viable option. The main advantage is that there is no intestinal mucosa in the augmented bladder. The major disadvantage is that dilated ureter with a non-functioning kidney is rarely available.

Different segments of the gastrointestinal tract like stomach, ileum and sigmoid can be used successfully for bladder augmentation. The advantage is that plenty of tissue available and good long-term capacity can be achieved. However, there is no one 
bowel segment is the best choice in all patients, to date most of the paediatric urologist prefers to use the ileum in children for augmentation (1). Probably it is because ileum produces less mucus and less expressed peristaltic contractions than sigmoid, the metabolic complications associated are less severe, it is easy to mobilise and it is theoretically sterile (2). Stomach is reserved for patients with short bowel syndrome, renal insufficiency and acidosis (1).

Tissue engineered bladders are still not an available option at present.

\subsection{Clam ileocystoplasty}

The clam ileocystoplasty is a well-established and popular technique of bladder augmentation in childhood (2) (Figure 1).
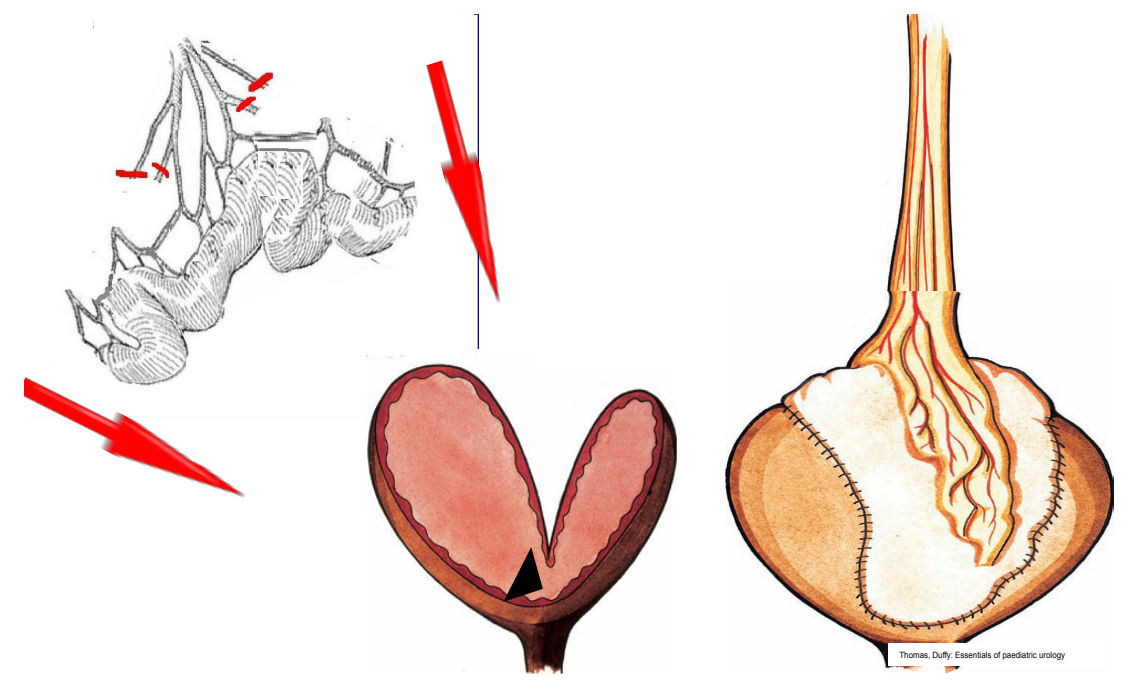

Figure 1.

Clam ileocystoplasty: Mobilisation of the ileum, detubularisation and bladder augmentation

The key to the successful ileocystoplasty is the incision of the non-compliant bladder wall deep into the pelvis down to the trigone in order to avoid a diverticulum like neobladder and to provide adequate margin for augmentation. The detubularised ileum flap therefore has to reach to the bottom of the divided bladder on a reliable vascular pedicle without significant tension. Usually, vessels at the level of the primary, secondary and the tertiary arcades of the mesentery are dissected to create adequate long pedicle for the ileum flap ( $\mathrm{T}$ - shaping) (2) (Figure 2). 


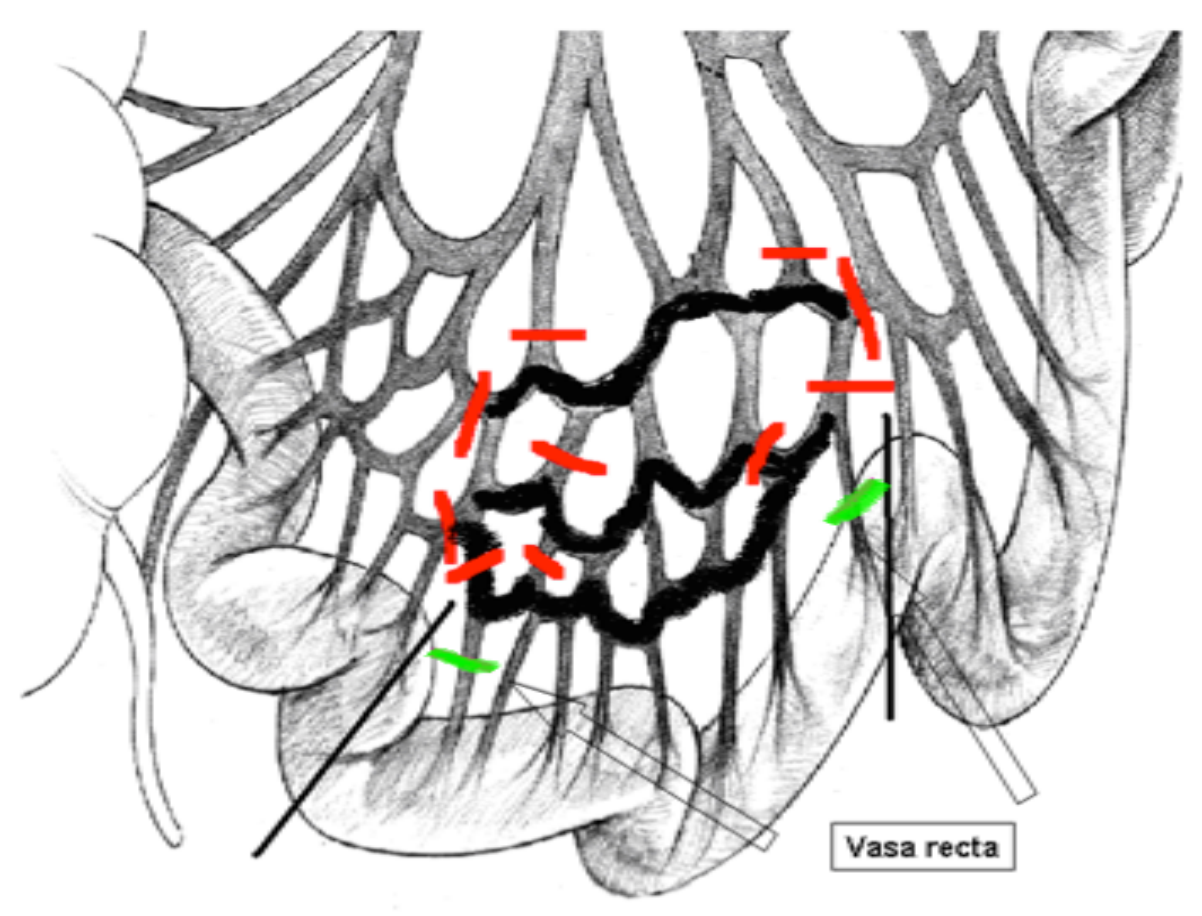

Figure 2.

"T-shaping": Primary, secondary and tertiary arcades indicated with thick black line. The red lines indicate ligation and dissection of vessels during $\mathrm{T}$ shaping. The green lines indicate further possible dissection of vasa recta beyond the tertiary arcade.

\subsubsection{Concerns about ileocystoplasty}

\subsubsection{Short mesentery}

Despite the "T-shaping" it may be difficult to gain enough length in patients with shortened mesentery caused by previous surgery, peritonitis, peritoneal dialysis or ventriculo-peritoneal shunt $(1,3)$. The use of sigmoid colon for cystoplasty is an alternative (4) in this situations, but it may result in a bladder with less compliance and more mucus secretion $(1,2)$.

Several techniques have been described for lengthening the small bowel mesentery not only in reconstructive urology, but in restorative proctocolectomy with ileal pouch anal anastomosis in ulcerative colitis or familial adenomatous polyposis. These techniques usually involve meticulous dissection, selective division of mesenteric blood vessels, "stepladder incision" of the mesenteric peritoneum $(5,6)$ and even vein grafting of the superior mesenteric artery (7). These techniques usually not applied with ileocystoplasty. 


\subsubsection{Mucus production}

The intestinal mucosa within the augmented bladder is continuing secreting mucus. The mucus will not solve in the urine. It can obstruct the catheters and prevent full drainage of the bladder. It is accumulating in the bladder and significantly increasing the risk of urine infection. It may serve as a nidus and can induce stone formation. Patients need to perform regular washouts to reduce accumulation of mucus in the augmented bladder, however, this is not very convenient and often forgotten. Colonic segment produce more mucus than ileum. Gastric segment produce less mucus but it secretes hydrochloric acid and the on-going chloride loss and decreased oral intake may lead to severe alkalosis and haematuria dysuria $(1,2)$.

\subsubsection{Metabolic issues}

The intestinal mucosa absorbs chlorine and ammonia from the urine. Hyperchloremic acidosis in children with augmented bladder can lead to fatigue, weakness and anorexia. Increased urinary acid load may lead loss of bone buffers even if no frank acidosis diagnosed. This could have long term consequences like bone demineralisation and growth retardation. Gastric mucosa is a natural barrier for acid and chloride and could be considered for bladder augmentation however, as it mentioned above the on-going loss of hydrochloric acid may lead to other complications $(1,2)$.

\subsubsection{Malignancy}

The intestinal mucosa exposed to urine and potential adenocarcinoma development $(1,2)$. The estimated risk of carcinoma in patients with uretrosigmoidesotomy is 7000 fold higher than age matched controls. The $\mathrm{N}$ nitroso compounds formed from the mixture of the faces and urine was found carcinogenic. These compounds have been found in the urine of patients with augmented bladder and thought to be contributing to tumour development. The growth factors produced at the anastomotic site in the augmented bladder due to inflammation may be responsible as well.

\subsubsection{Flap contraction after augmentation with mucosectomised intestinal}

\section{flaps}

William Shoemaker and his colleagues were awarded with the first prize on the essay competition of the American Urological Association in 1955 for the idea using 
mucosectomised reversed ileal flaps for bladder augmentation in dogs following subtotal cystectomy (8-11). It seemed that the intestinal mucosa-related complications would no longer be a concern after mucosectomised reversed flap bladder augmentation. The technique was then applied in 4 patients, however, contraction of the flaps occurred and the technique was abandoned (11). Thirty years later Oesch (1988) revised this procedure and reported no contraction and full epithelisation of the caecal segment in rats after mucosectomy (12). Salle (1990) was not able to reproduce these good results in dogs with clam ileo- or colocystoplasty (13). However, the reverse flap augmentation was abandoned believing that vascular compromise of the flaps during the procedure may have caused contraction.

Research has focused on non-reversed flaps, but contraction of the flap remained major concern. Motley et al (1990) performed sero-muscular cup shape sigmoid cystoplasty and paid special attention to the vascular histology of the flaps without finding any evidence of vascular thrombosis (14). Salle (1997) concluded that vascular compromise may not play a role in flap contraction studying rabbits that had sero-muscular segments constructed using the gastric fundus fixed to the anterior abdominal wall (15).

It has been hypothesised that the tissue contraction may be due to the exposure of the denuded intestinal surface to urine and/or prolonged postoperative decompression of the augmented bladder. Therefore research has focused on using urothelium to cover the denuded surface and the use of splints to prevent the effect of long-term drainage leading to collapse of the augmented bladder $(16,17,18)$. To some extent, these varying approaches have led to acceptable results; nevertheless, the contraction of the intestinal flaps still remains a major concern.

\subsection{Continent urinary stomas in children}

\subsubsection{Mitrofanoff principle}

The appendix has been used most commonly as a catheterisable stoma by the paediatric urologists and reconstructive surgeons since Mitrofanoff described it in 1980 (19). There are several benefits using the appendix for catheterisable stoma. The mesentery supplies the appendix in the middle portion and leaves the two ends not 
bulky, thus making implantation into the bladder easy. It is usually long enough to be implanted into the bladder in an antireflux manner and to reach the skin level through the abdominal wall. It is very important that it is naturally straight and narrow to smoothly guide catheters into the bladder (Figure 3).
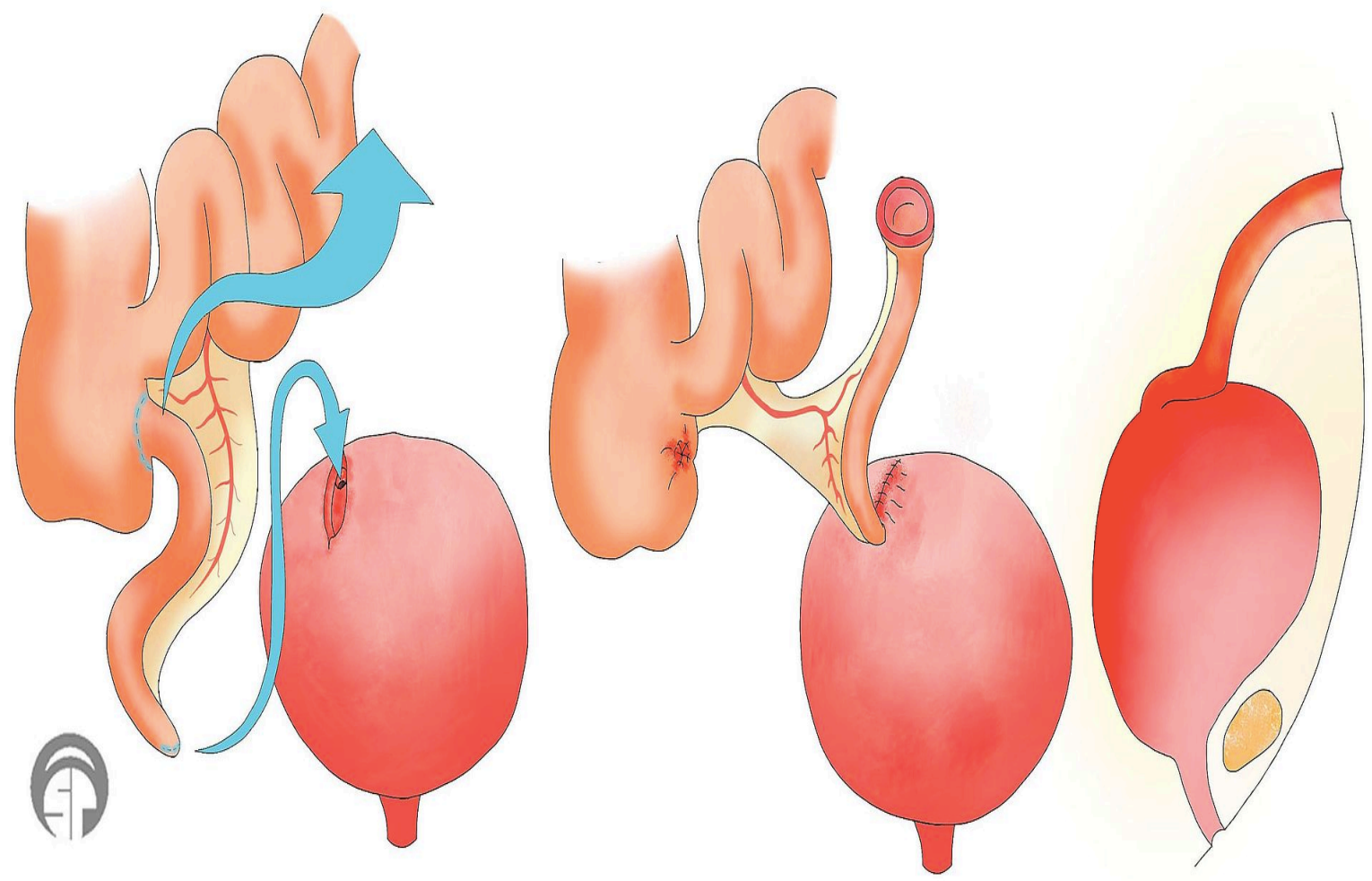

Figure 3.

The Mitrofanoff procedure for catheterisable urinary stoma Source: https://upload.wikimedia.org/wikipedia/commons/1/11/Mitrofanoff.jpg

\subsubsection{The Monti procedure}

The occasional lack of a suitable appendix and the increasing use of the MACE (Malone Antegrade Continence Enema) procedure have expanded the need for alternative tissues for the Mitrofanoff channel. The Monti channel, transversally tubularised ileum, is a well-known alternative (20). The length of the Monti channel is determined by the width of the ileum. It is usually $6-8 \mathrm{~cm}$ long (Figure 4). 
A

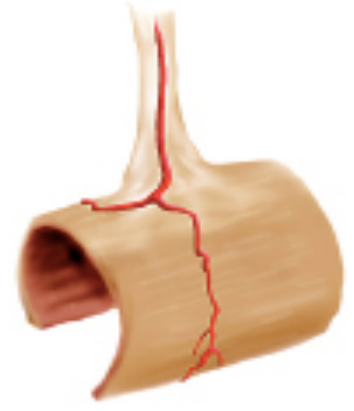

B

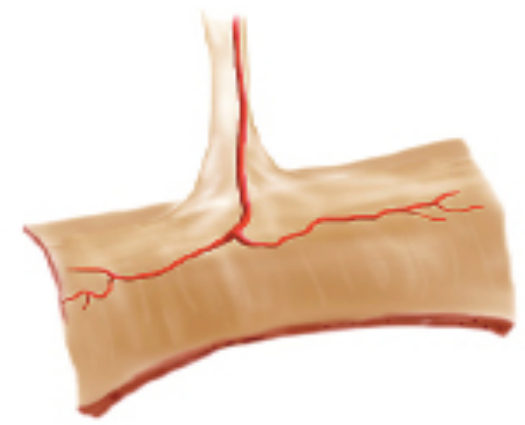

C

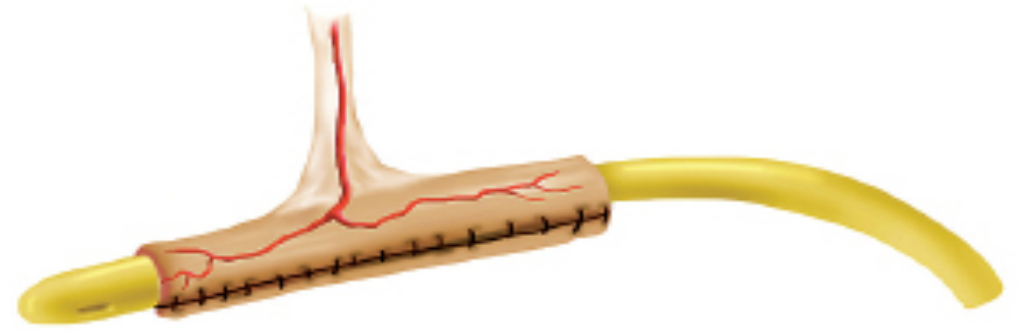

Figure 4.

Monti procedure: A: detubularisation of an ileum segment, B and C: retubularisation above a catheter Source: http://www.scielo.br/scielo.php?script=sci_arttext\&pid=S1677-55382010000300008\&lng=en\&nrm=iso\&tlng=en

\subsubsection{Long channels: Double Monti, Casale technique}

In adolescence, especially in wheelchair-bound children, the Monti channel is not long enough to reach the abdominal wall, especially if the stoma is planned to reach the umbilicus. The demand of longer channels resulted in alternative techniques like double Monti and Casale tubes $(21,22)$ (Figure 5). 


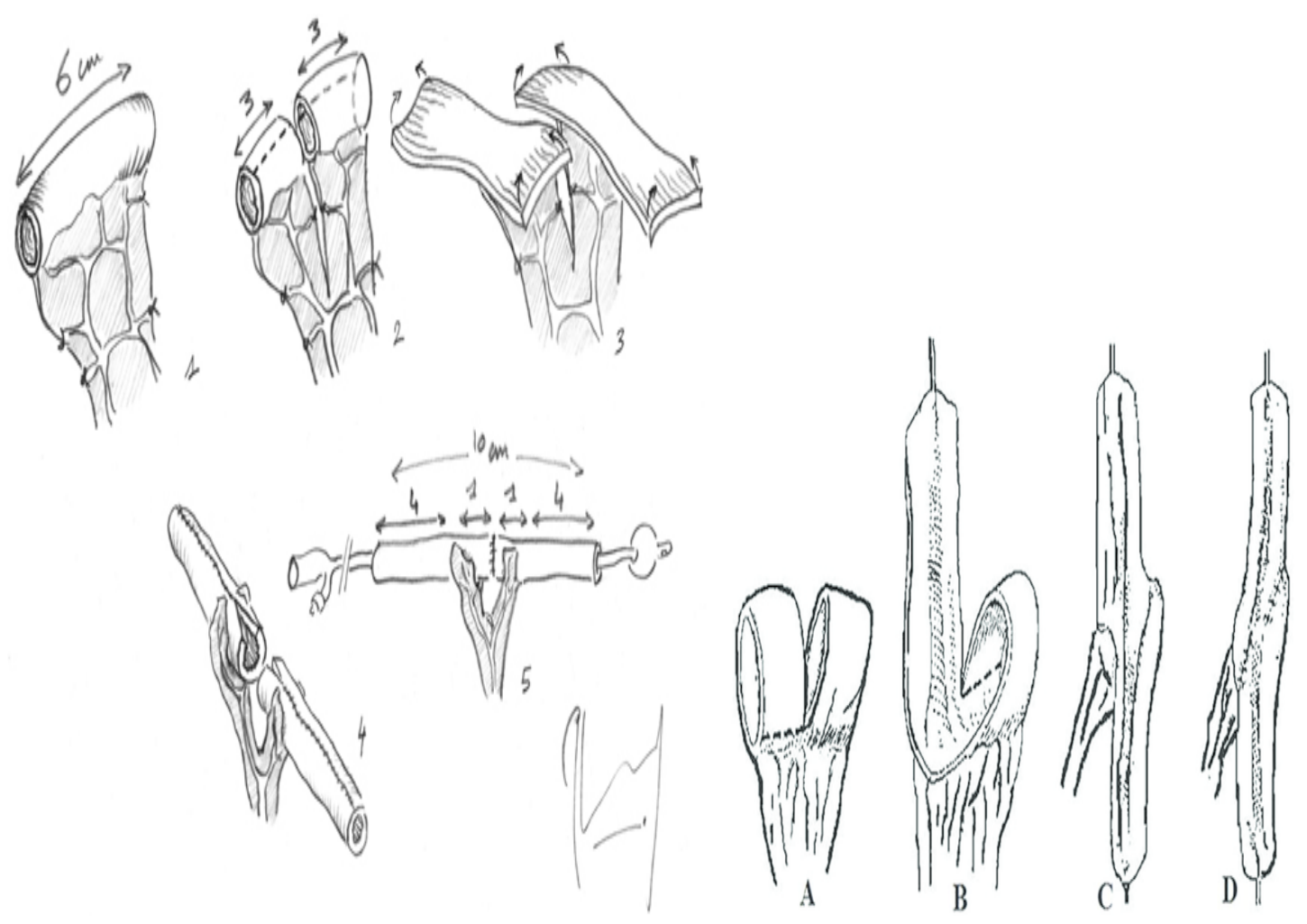

Figure 5.

Left: The double Monti Right: the Casale technique

Source: https://www.researchgate.net/figure/6138296_fig8_Figure-4-Technical-principles-of-double-Monti-tube http://numonthly.com/9443.fulltext

\subsubsection{Concerns of Long channels (Double Monti, Casale technique)}

The double Monti consists of 2 Monti tubes anastomosed. The circular anastomosis between these two tubes is a weak point. The channel can be narrow, angulate or perforate at this point. With the Casale technique, the two half of a bowel segment are detubularised at the opposite sides and the bowel strip stretched to a long straight strip. The middle this strip requires some excision and suturing and the strip can be tubularised along a catheter. There is no circular anastomosis in the Casale tube, however, due to the shape memory of the tissues there is a potential angulation in the middle of the Casale channel, which may be associated with higher complication rate (Figure 6) (21,22). 

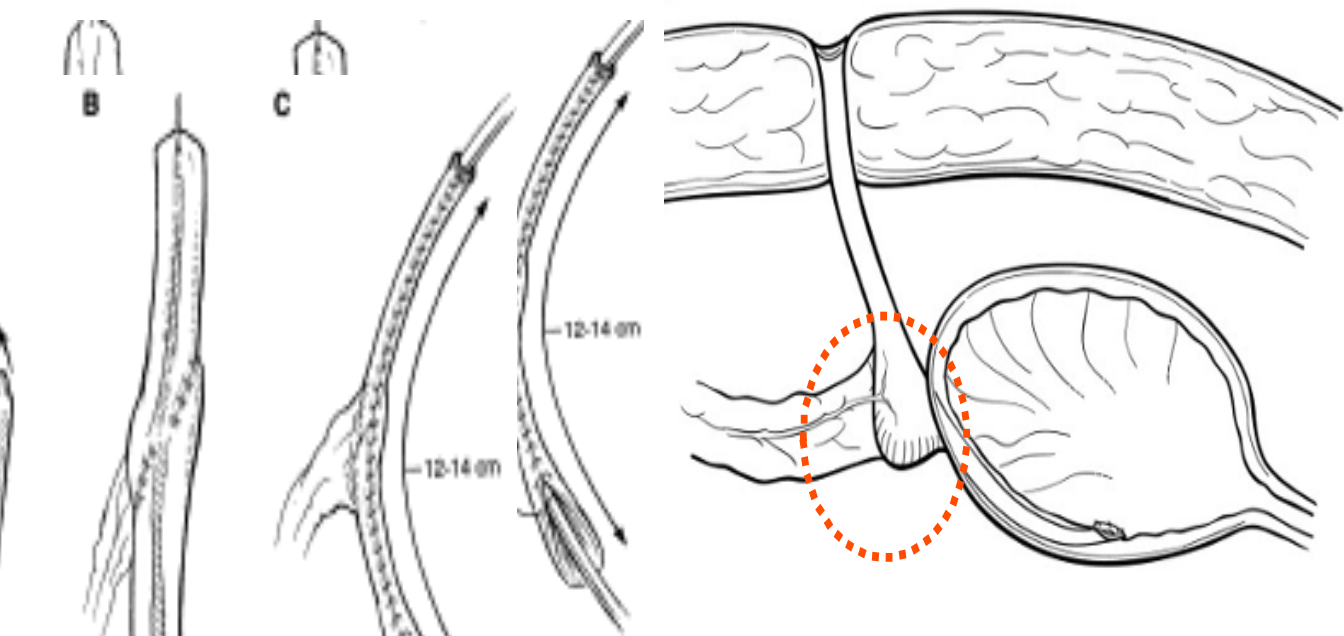

Figure 6.

Left: the straightened Casale channel Right: The Casale channel implanted into the bladder. Encircled: the site of potential complication. (Source: 15,16)

\subsection{Intestinal intramural microcirculation}

According to present knowledge, the blood supply of the bowel is segmental and the mesenteric vessels divide to terminal arteries called vasa recta (VR) before they reach the intestine. The VR encircle and supply both halves of the intestine remaining perpendicular to the long axis of the bowel (23).

During intestinal reconstruction procedures, surgeons rarely rely on the intestinal intramural circulation and as a general rule no bowel segment without mesentery directly attached should be used for reconstruction. When detubularisation of the bowel is performed, it is done mainly along the antimesenteric line.

Anatomists hypothesised intramural communication may exist between the opposing and the neighboring VR (antimesenteric and longitudinal intramural vascular anastomoses) (23-27), but the efficacy of these connections have never been measured. However, research on intestinal microcirculation and wound healing is very popular nowadays $(28,29)$.

If there were direct convincing evidence for effective intramural communications between anterior and posterior branches of the VR (antimesenteric intramural vascular anastomoses) and the neighbouring VR (longitudinal intramural vascular anastomoses), surgeons would feel safer relying on intramural circulation. 


\subsection{Imaging of the microcirculation by in vivo intravital videomicroscopy}

There are many ways to monitor microcirculation. Non-invasive intraoperative imaging methods are able to record morphological parameters ie. diameter and density of the vessels, the length of perfused (open) and non-perfused (closed) capillaries, or measuring dynamic parameters like velocity of the circulating red blood cells (30). Assessment of microcirculation can be performed with single-point measurements (Laser Doppler Flowmetry) or and imaging methods for example Orthogonal Polarization Spectral Imaging (OPS) technique. Imaging methods visualise larger area and it is more preferable due to the spatial heterogeneity of the micro vascular bed (31).

OPS imaging technique, first described in 1999, can be used to visualise microcirculation by imaging erythrocytes containing small arterioles, venules and capillaries less than $150 \mu \mathrm{m}$ in diameter. The OPS devices are emitting $550 \mathrm{~nm}$ linearly polarized light while recording the light reflected from the haemoglobin stored in the erythrocytes at a $90^{\circ}$ angle (orthogonal) that way the direct reflection is eliminated (32). The reflected light depolarised forms an image on the image sensor as if the tissue were transilluminated (33). The intravital videomicroscope provides a magnified real time video image of the capillary flow without any contrast medium or fluorescent cell labelling as it is necessary in fluorescent in vivo videomicroscopy. It is simple and can be used intraoperatively.

In vivo OPS videomicroscopy has been used to study changes in tissue microcirculation in different conditions like sepsis and monitor consequences of vascular ischemia of intestine (34). Bajory et al. compared OPS technique and intravital fluorescence microscopy in an experimental rat model of testicular torsion and demonstrated the non-invasive OPS technique is suitable to detect fine disturbances of testicular microcirculation even 240 minutes after re-established perfusion (35). OPS was sensitive enough to demonstrated the beneficial effect of selective endothelin-A antagonists to the testicular microcirculation (36).

The greatest advantage of the OPS technique is the simplicity and the direct visualisation of the microcirculation; however, there are some limitations like relative blurred image of the capillaries and the time consuming off line data analysis. In the advanced Sidestream Dark Field Imaging (SDF) microscope (the successor of the 
OPS) an the latest third generation Incident Dark Filed (IDF) microscope (Cytocam) the light source is made up of concentrically placed light emitting diodes surrounding the optics and the pulsation of the emitted light is synchronised with the camera frame rate. This result in sharper image and the whole microscope and the light source is integrated in one handheld device. There is another disadvantage of these instruments the lens needs to be in contact with the tissue. This makes both instruments sensitive for pressure artefacts (31).

Most advanced, sophisticated non-contact imaging methods like Laser Doppler Perfusion Imaging (LDPI) and Laser Speckle Contrast Imaging (LSPCI) are not sensitive for pressure artefact. The LDPI is combining several single-point laser Doppler flowmeter over a tissue surface can create an image of microcirculation. This technique requires long measurement time $(31,37)$.

The LSPCI technique is based on the "laser speckle" phenomenon, the laser light illuminating the tissue scatters irregularly creating a special pattern, which can be detected by a camera, this pattern changes with movement (blood flow) within the tissue and computer can analyse image with color-coding. The measurement is fast. The major disadvantage of both techniques they are more susceptible to motion artefacts and measure relative flow and need to be very accurately calibrated $(31,38)$.

Using these more advanced imaging methods might have improved our data quality however, at the time of our studies only the OPS technique was available at our institution. On the other hand, the simplicity and the significant experience with this technique was reassuring we can indeed rely on this method to understand the effect of surgical interventions to the tissue microcirculation and design new safe procedures without compromising blood supply (Figure 7).
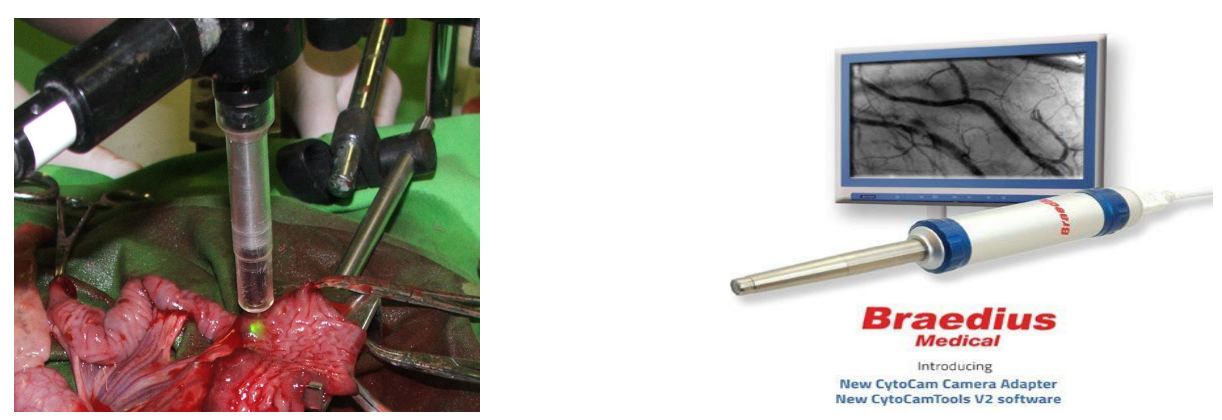

Figure 7.

Left: In vivo microscopy the OPS transducer (emitting green light) is placed over a bowel Cytoscan A/R, Cytometrics, PA, USA Right: our latest generation IDF (Cytocam, Braedius, Netherland) 


\section{MAIN GOALS}

2.1. Assess the clinical importance and efficacy of the bladder augmentation and continent cutaneous diversion in patients after failed bladder exstrophy repair

Our aim was to review the results from a single exstrophy center of salvage continence surgery after failed staged reconstruction for bladder exstrophy.

\subsection{Explore intramural microcirculation of the ileal flap used for augmentation}

Our aim was to examine the efficacy of the longitudinal and antimesenteric intramural intestinal vascular anastomoses using intravital videomicroscopy in a porcine model.

\subsection{To develop new technique for augmentation if mesentery short}

We investigated other options to create alternative ileum flaps, which reach further into the pelvis. We hypothesized that we can rely on the antimesenteric intramural communication of the vasa recta (VR) within the intestine observed by anatomists (25-27) and can detubularise the ileum adjacent to the mesentery rather than along the antimesenteric line without compromising the microcirculation. Monti (1997) and Casale (1999) also found that a short ileal segment detubularised paramesenterically remained viable and can be used for continent urinary stoma for intermittent catheterisation $(20,21)$. Ileum detubularised along a paramesenteric line will result in alternative ileal flaps reaching deeper into the pelvis (Figure 8.).

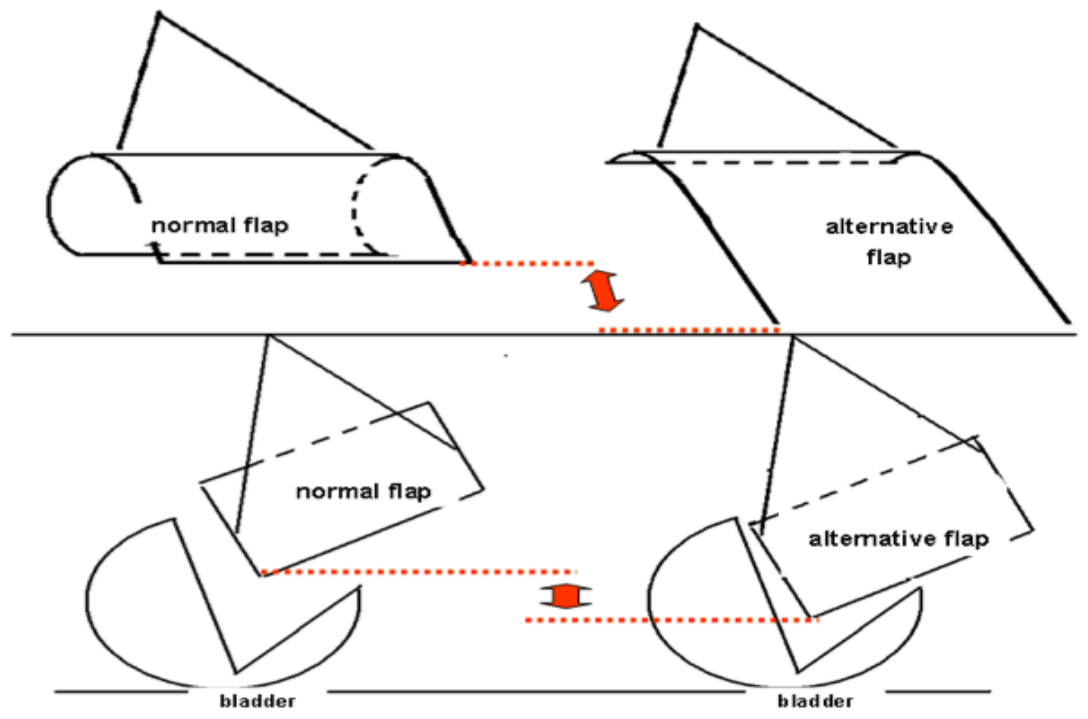

Figure 8.

Left: Ileum detubularised along the mesenteric line Right: Ileum detubularised along the paramesenteric line (reaches longer into the pelvis) 
During T-shaping usually no vessels dissected beyond the level of the tertiary arcades, but ligation of a few VR should give more length to the flap. Neighboring VR have been reported to have communicating anastomoses and ligation of some vessels may therefore not compromise microcirculation of the adjacent bowel segment (24-27). Our aim was to assess the viability and safety of the alternative flaps detubularised along the paramesenteric line and measure how many VR could be sacrificed beyond the tertiary arcades.

\subsection{Effect of mucosectomy on flap microcirculation and flap contraction}

We found interesting that Cheng (39) reported no contraction of full thickness (intact mucosa) ileal flap used for reverse flap augmentation in a dog. This gave us the idea to review the experience with the reverse flap augmentation to find out if mucosectomy has significant effect on the microcirculation of the ileal flaps during reverse clam ileocystoplasty. Since the omentum has been used clinically to promote revascularization and healing of ischemic tissues (40-43), we also examined whether omentopexy prevents the contraction.

\subsection{To test new concept to create long and straight continent urinary stomas}

In short bowel syndrome, Spiral Intestinal Lengthening and Tailoring (SILT) technique is used to tailor the diameter of the dilated bowel, we hypothesized that SILT can be applied on normal caliber bowel to create a long and straight viable catheterisable channel (44-46.) (Figure 9).

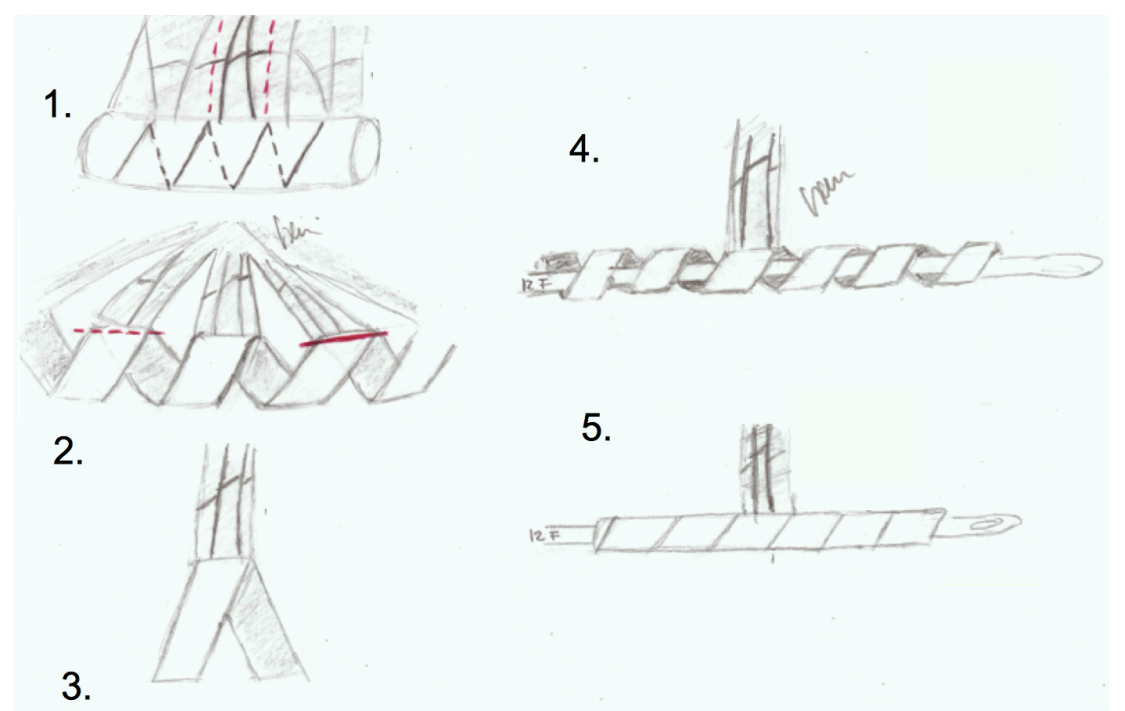

Figure: 9.

Steps of SILT for catheterisable channel. 


\section{MATERAIL AND METHODS}

\subsubsection{Patients and methods}

We retrospectively reviewed the records of 32 patients who underwent our standard protocol of treatment. A total of 21 referred patients and 11 patients treated at our exstrophy unit underwent salvage continence procedures after failed reconstruction. Manchester Patients:

According to protocol, the 11 patients originally treated at our exstrophy unit underwent primary bladder closure and bilateral posterior iliac pelvic osteotomy at age 2 days to 3 weeks. Urinary diversion and gallows traction was maintained for 4 weeks postoperatively and all wounds healed primarily. The upper urinary tract was monitored by ultrasound every 6 to 12 months. Those patients showed urinary tract dilatation started clean intermittent catheterization (CIC). If hydroureteronephrosis persisted despite CIC clam ileocystoplasty was performed. If CIC was not well tolerated cutaneous urinary diversion was performed according to Mitrofanoff principle. Male patients underwent Cantwell-Ransley epispadias repair at age 12 to 18 months. Bladder capacity was assessed at ages 1,3 and 5 years with water-soluble contrast introduced trough a urethral catheter at a pressure of $20 \mathrm{~cm}$ water.

At age 5 years patients who were still incontinent were considered for continence surgery. Those patients with a bladder capacity more than $85 \mathrm{cc}$ and preserved upper tract were offered modified Young-Dees bladder neck repair. Patients unable to empty the bladder spontaneously per urethra after the repair were started on CIC per urethra (1 patient) or continent cutaneous diversion with or without bladder augmentation according to the bladder capacity. Those patients who remained incontinent proceeded to bladder neck closure, bladder augmentation and cutaneous diversion (2 patients). Cutaneous diversion and Mainz pouch II was also proposed as alternative option. Incontinent children with bladder capacity less than $85 \mathrm{cc}$ were candidates for bladder augmentation, bladder neck closure and cutaneous diversion (3 patients). However, 2 girls who tolerated urethral catheterization were offered bladder neck repair and bladder augmentation. Bladder substitution using sigmoid (1 patient) was performed if the native bladder was not considered usable for reconstruction and the child or the family did not accept cutaneous diversion or Mainz II. Pouch (1 patient). 
Referred patients:

The 21 patients referred with the same indications were similarly considered for salvage continence surgery. Poor bladder capacity was seen in 18 patients, upper tract deterioration was noted in 8 patients, failed bladder neck repair happened in 6 patients. Continence was defined according to the International Children's Continence Society terminology, as continent, intermittently continent and continuously incontinent.

\subsubsection{Research animals, anaesthesia:}

The experiments were approved by the Committee of Animal Research at the University Szeged (Permission no: I-74-14/2012 MÁB and V./1637/2013 ) The studies was performed on anesthetised Vietnamese mini pigs (weight: $25-30 \mathrm{~kg}$ ). The animals were kept under conventional circumstances, in standard cages, were fed with commercially available mixed food, were fasted 36 hours before surgery and had always free access to water. Anaesthesia was induced with an intramuscular injection of a mixture of ketamine $(20 \mathrm{mg} / \mathrm{kg})$ and xylazine $(2 \mathrm{mg} / \mathrm{kg})$ and maintained with a continuous infusion of propofol $(2 \% ; 50 \mathrm{ml} / \mathrm{kg} / \mathrm{min}$ i.v. $)$. Endotracheal tube was inserted and the animals were ventilated mechanically with volume-controlled ventilator. The tidal volume was set at $8-9 \mathrm{ml} / \mathrm{kg}$, and the respiratory rate was adjusted to maintain the end tidal carbon dioxide pressure between $35-45 \mathrm{mmHg}$. Norocarp $\mathrm{S}$ (carprofen; $4 \mathrm{mg} / \mathrm{kg}$ ) and normal saline infusion were administered via canulated ear vein. Hearth rate, $\mathrm{O}_{2}$ saturation, $\mathrm{pCO}_{2}$ and body temperature were continuously monitored by capnometry.

\subsubsection{In vivo microscopy}

The intravital OPS imaging technique (Cytoscan A/R, Cytometrics, PA, USA) was used for visualization of the microcirculation of the mucosa and the serosal surface (the latter in the in the $3^{\text {rd }}$ study after mucosectomy). Special care was taken to avoid pressure artefact. The lens was positioned over the tissue very gently until reasonable sharp image seen on the monitor. The microscopic images were recorded with an SVHS video recorder (Panasonic AG-TL 700). Microcirculatory evaluation was performed off-line by frame-to-frame analysis of the videotaped images. The capillary red blood cell $(\mathrm{RBC})$ velocity $\left(\mu \mathrm{m} \mathrm{s}^{-1}\right)$ changes were determined and capillary 
perfusion rate (CPR) were calculated from ratio of perfused capillary and total capillary length in the intestinal villi in 3 separate fields by means of a computerassisted image analysis system (IVM Pictron, Budapest, Hungary). The same technique was applied in all 4 experiments.

\subsubsection{Intramural microcirculation of the ileal flap}

Examination of antimesentric intramural vascular anastomoses: $10 \mathrm{~cm}-10 n g$ jejunal loops were isolated in anaesthetised pigs $(\mathrm{n}=5)$. Control Group: after antimesenteric incision the bowel loop was opened and the mucosal microcirculation has been recorded with orthogonal polarisation spectral (OPS) imaging technique at the antimesenteric edges of the opened bowel strip. In Group 1 longitudinal incision was performed on the bowel loop between the mesenteric and antimesenteric border in the middle. After detubularisation the microcirculation has been recorded at the edge of the opened bowel strip beyond the antimesenteric line. In Group 2 the loops were cut next to the mesenteric line. After detubularisation the microcirculation has been recorded at the edge of the opened bowel strip beyond the antimesenteric line (Figure 10.).

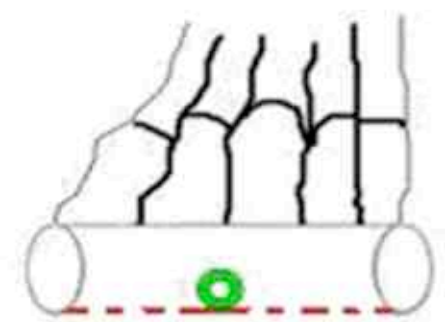

Control

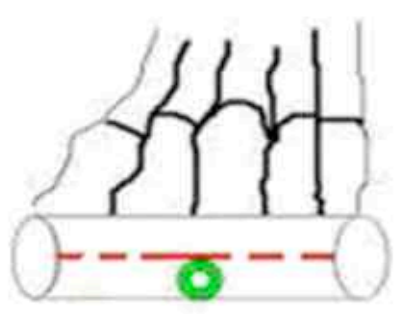

Group 1.

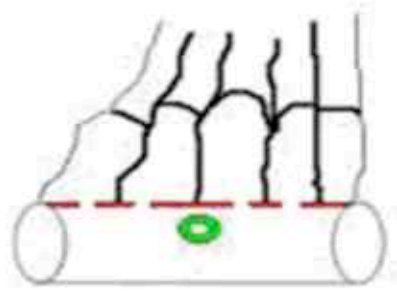

Group 2.
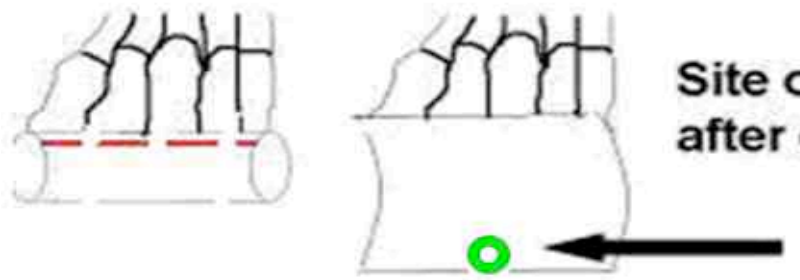

Figure 10.

Detubularisation of the intestinal loops marked red, the site of measurement green 


\section{Examination of longitudinal intramural vascular anastomoses:}

Mucosal microcirculation was recorded on a continuous jejunum after antimesenteric incision. Ligation of 2, 4 and 6 neighbouring vessel was performed sequentially and the microcirculation was recorded on the bowel at the midpoint of these vessels There was some irregularity of vessels in the mesentery of the pigs. Maximum 2 vessels running next to each other were considered as vasa recta. The same study was done on a jejunum segment with free end starting the ligation from the free end of the bowel loop and measuring the microcirculation at the free end (Figure 11).
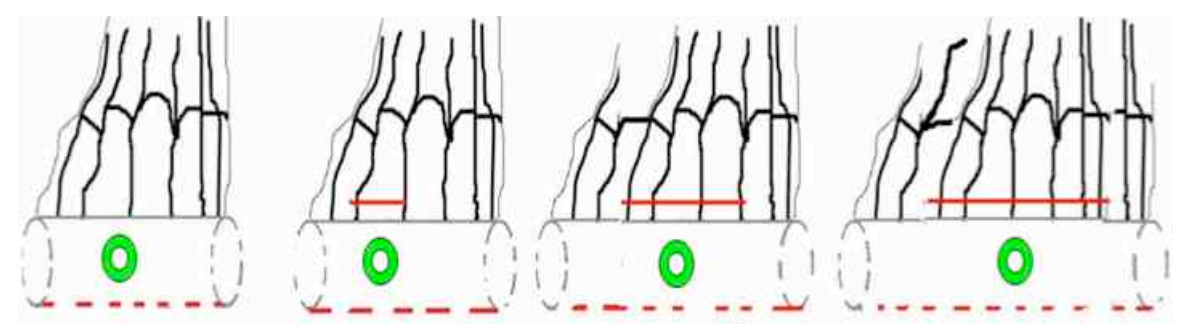

continuous bowel loop
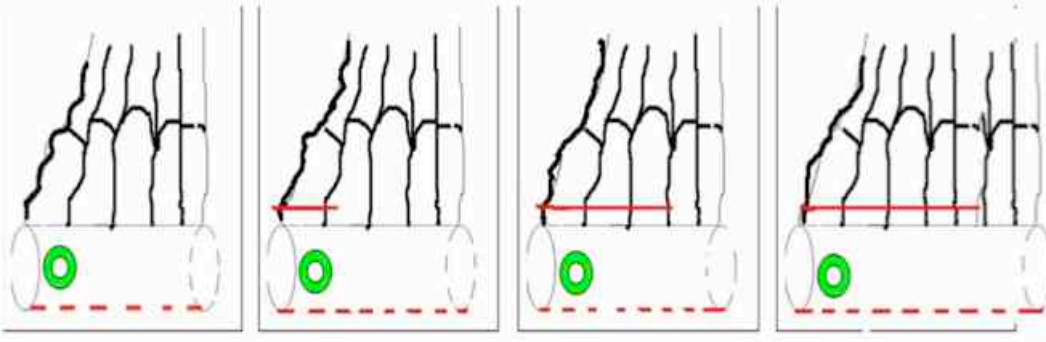

\section{loop with a free end}

Figure 11.

Detubularisation of the intestinal loops marked red, the site of measurement green

\subsubsection{New technique for augmentation if mesentery short}

\section{Animals, instrumentation and surgery}

The animals $(\mathrm{n}=5)$ were placed in a supine position on a heating pad and midline laparatomy was performed. Adjacent ileal segments were isolated. In control group the ileum was detubularised along the antimesenteric line. In AF group the ileum was detubularised along the paramesenteric line. Subsequent ligation and dissection of 0 , 1, 2, 3 and 4 VR was performed in both groups starting from the free end of the segments. The length of the flaps were measured from a point marked with a suture on the base of the mesentery and the difference between the two groups was recorded (Figure 12). 


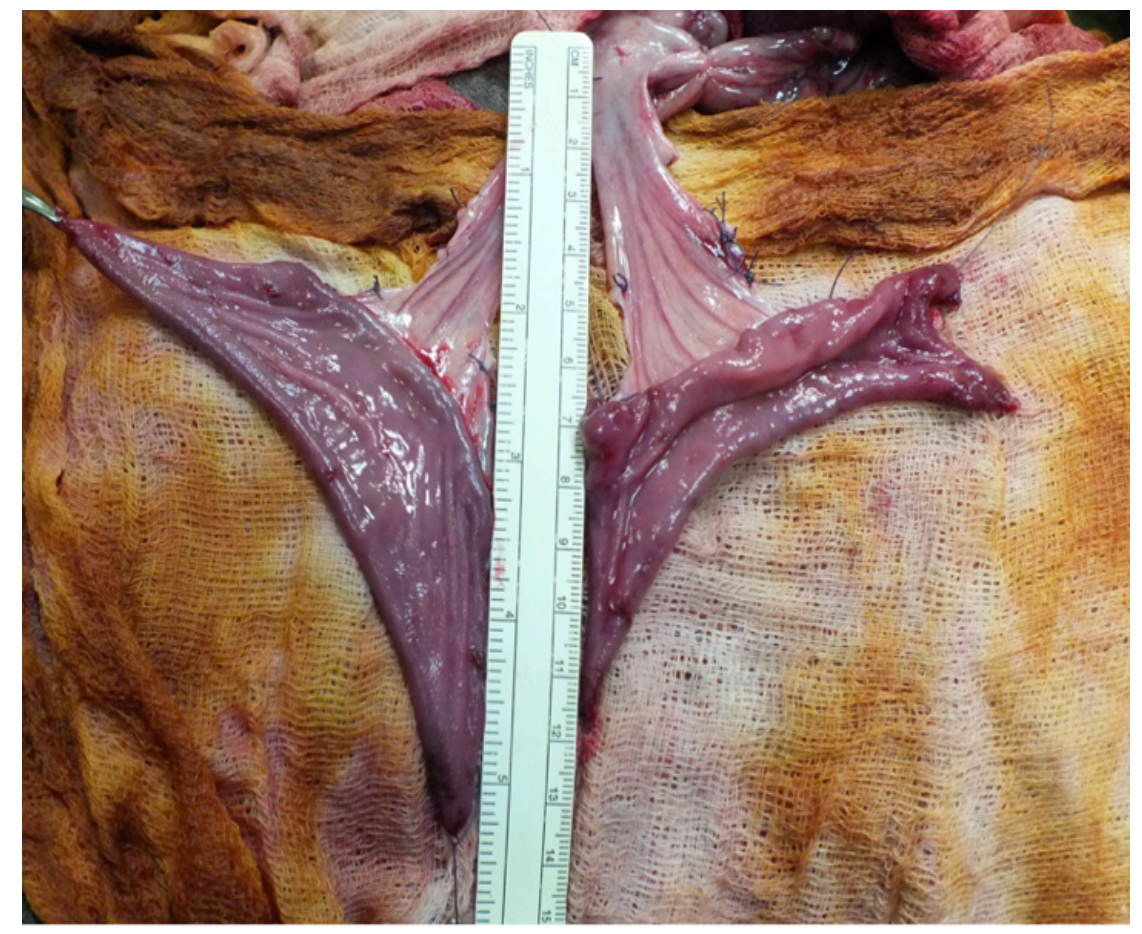

Figure 12.

Left: paramesenteric (alternative) detubularised ileal flap, Right: (antimesenterically detubularised) normal flap. Note the alternative flap reaches longer. Vasa recta are divided and ligated at the ends the segment where the mesentery met the bowel. The mesentery with the ligatures retracted high up.

Intravital videomicroscopy was performed to examine the microcirculation of the flaps mucosa. At the end of the measurements the flaps were removed and new $20 \mathrm{~cm}$ long ileum was isolated for the clam ileocystoplasty.

After recovery, all animals were kept on fluids only for $24 \mathrm{hrs}$, and liquid food was then available for 48-72 hrs after which they were fed normally. Analgesia (carprofen) and antibiotics (enrofloxacin) were continued for 3 days postoperatively.

After four weeks the animals were anesthetized again, and the augmented bladders were examined and removed. Specimens were harvested containing the distal suture line with the bladder and the ileal flap. Conventional hematoxylin eosin staining and light microscopy examination was performed.

The clam ileocystoplasty: The ileum segment was detubularised along the paramesenteric line on the posterior wall and the continuity of the ileum was then restored with single layer anastomosis. The bladder was incised down to the trigone 
and the ileum flap was sutured to the bladder using 5/0 Vicryl. 12 F Malecot catheters were placed urethrally.

Histopathological analysis: Full-thickness tissue biopsies taken from the bowel bladder junction on week 4 after surgery were analysed in each animals. The tissues were fixed in $6 \%$ buffered formalin, embedded in paraffin, cut into $4-\mu \mathrm{m}$-thick sections and stained with hematoxylin and eosin.

\subsubsection{Effect of mucosectomy on flap microcirculation and flap contraction}

Clam ileocystoplasty was performed using $15 \mathrm{~cm}$ long ileum segments in 2 groups. First the ileal segment was isolated detubularised along the paramesenteric line (Figure 13.). The bowel was kept warm with $0.9 \%$ saline solution . The detubularised bowel strips were placed on wet gauze and the width was measured with linear ruler under no tension and the microcirculation was recorded on the serosal surface. Than mucosectomy was applied. In the sero-muscular group the mucosa and the submucosa was peeled off the sero-muscular layer in one piece. It was easy to separate the submucosa from the muscular layers at one corner of the flaps with fine forceps. Injection of saline into the submucosa was not necessary. In the sero-musculosubmucosal group only the mucosa was scraped off with the back of a forceps from the bowel at the level of the mucosa propria. Surgical loops with $2.5 \mathrm{X}$ magnification were used to make sure no mucosa islands left behind (Figure 14).

The microcirculation was rerecorded in each group after mucosectomy procedure on the serosal surface. Clam ileocystoplasty was performed in each group with the serosa facing inside (reverse fashion), with non-absorbable 4/0 Prolene suture. The denuded surface of the ileal flap facing the abdominal cavity was covered with the omentum (Figure 15.) in both groups, anchored by 4/0 Polysorb suture. 

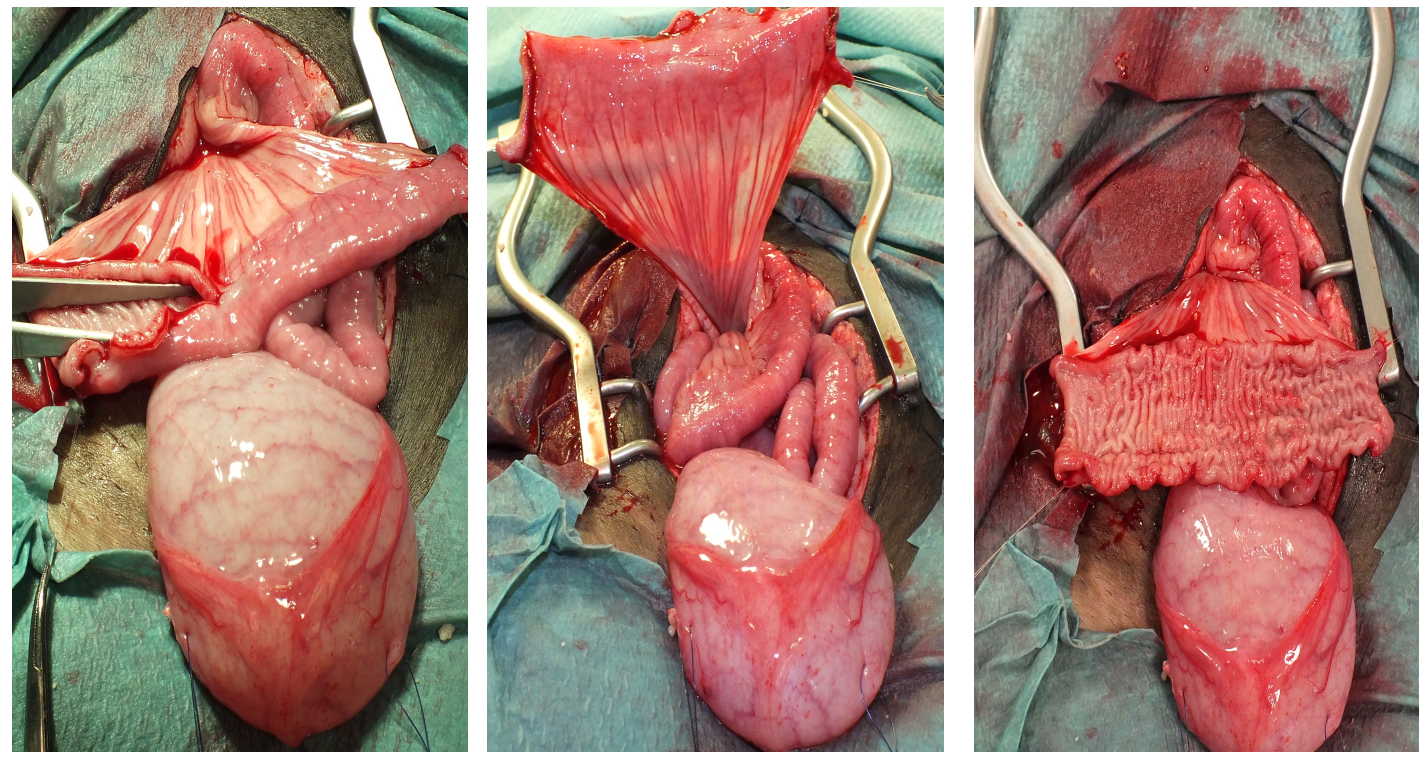

Figure 13.

The ileum is detubularised along a paramesenteric line on the anterior surface of the bowel to allow to face the serosa inside of the bladder

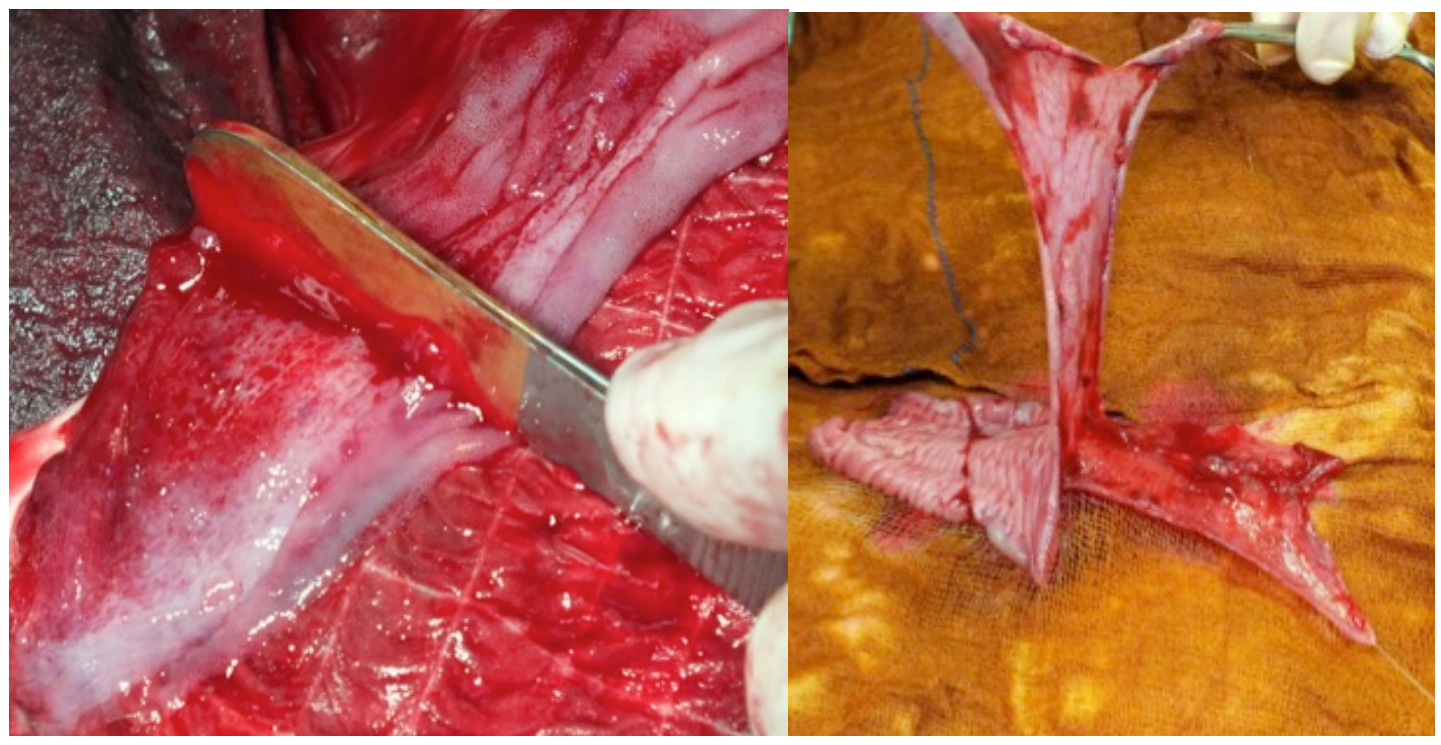

Figure 14.

Left: scraping off the mucosa. The encircled grayish shiny area where mucosa still on, the red area the mucosa is off. Right: mucosa and submucosa is peeled off from the sero-muscular layers. 


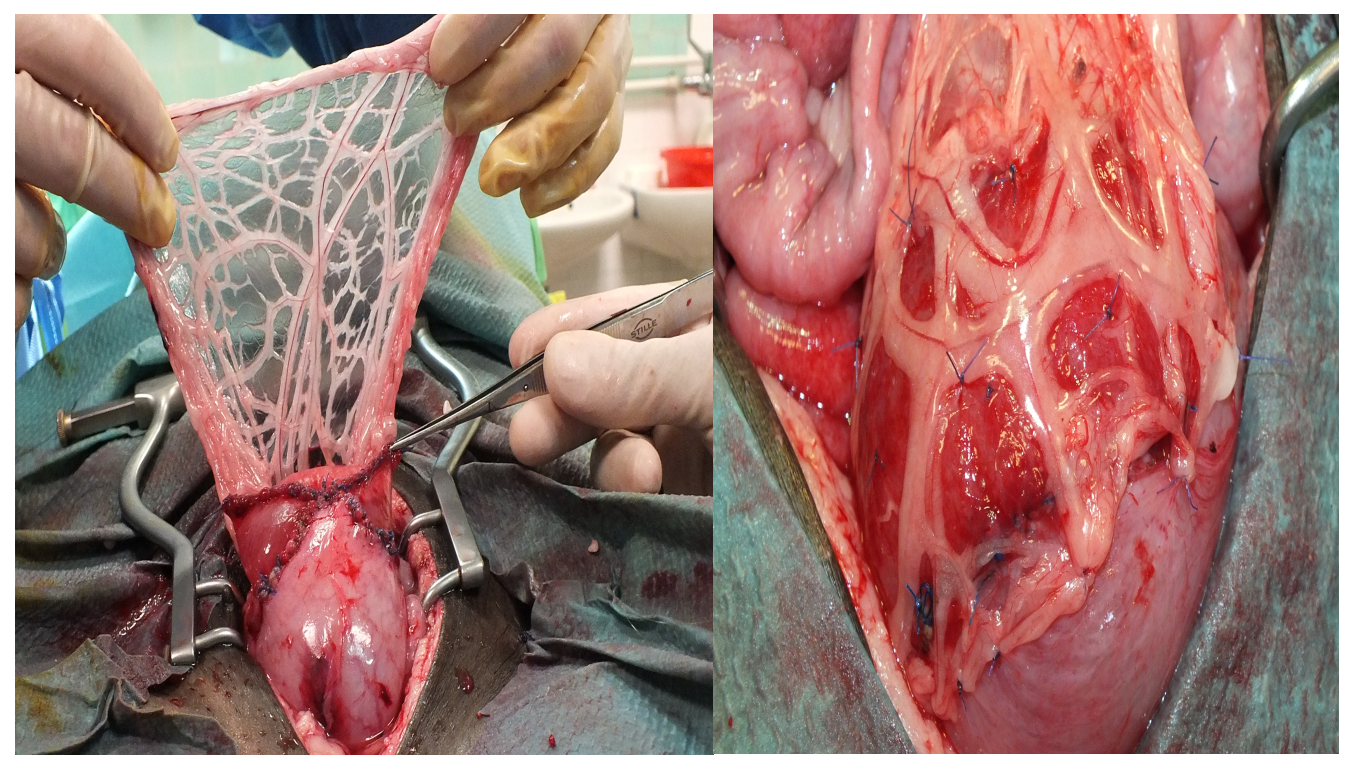

Figure 15.

The raw surface of the ileal flaps on the augmented bladder was covered with the omentum.

Malecot catheters (12 F) were left in the urethra, the tip of the catheters being fixed with $5 / 0$ Polysorb to the bladder mucosa. The end of the catheters needed to be cut at the level of the external urethral meatus since the animals are not tolerating catheters hanging out of their body and sutured to the labia minora with 5/0 Polysorb to keep them in situ for 5-7 days.

The animals were sacrificed after 8 weeks. The bladder was removed, opened, the non-absorbable suture line was identified and the ileal flap dimensions were measured. Shapiro-Wilk normality test and Paired t- test were applied. Means and standard deviation are given; $p$ values $<0.05$ were considered significant.

\subsubsection{New concept to create long and straight continent urinary stomas}

Median laparatomy was performed after skin preparation with povidone-iodine (Betadine, Egis, Budapest, Hungary) and sterile draping. Clam ileocystoplasty was performed. Another 6-8 cm long piece of ileum adjacent to the ileal bladder flap was mobilized with intact mesenteric blood supply. The spiral line was marked on the bowel approximately $15 \mathrm{~mm}$ apart with $60^{\circ}$ angle to the longitudinal axis of the bowel. When the incision was completed, the mesentery was incised perpendicularly where the spiral incision line met the mesentery. The maximum length segment 
hanging on a single $1.5 \mathrm{~cm}$ wide well vascularised mesentery was detached. The microcirculation was recorded in the middle and at the edges of the bowel strip

The bowel strips were then retubularised in a spiral fashion with interrupted 5/0 Vicryl sutures over a $12 \mathrm{~F}$ Malecoth catheter and were implanted in the bladder according to the Mitrofanoff principle. The distal end of the channels were brought out through the abdominal wall, sutured to the skin and secured to the fascia and peritoneum. The catheters were secured to the skin with $5 / 0$ vicryl and were cut at the level of the skin. Another $12 \mathrm{~F}$ Malecoth catheter was inserted into the urethra, cut at the level of the Rima pudendi, secured into the bladder mucosa and to the labia minora with 5/0 Vicryl stitches (Figure 16).

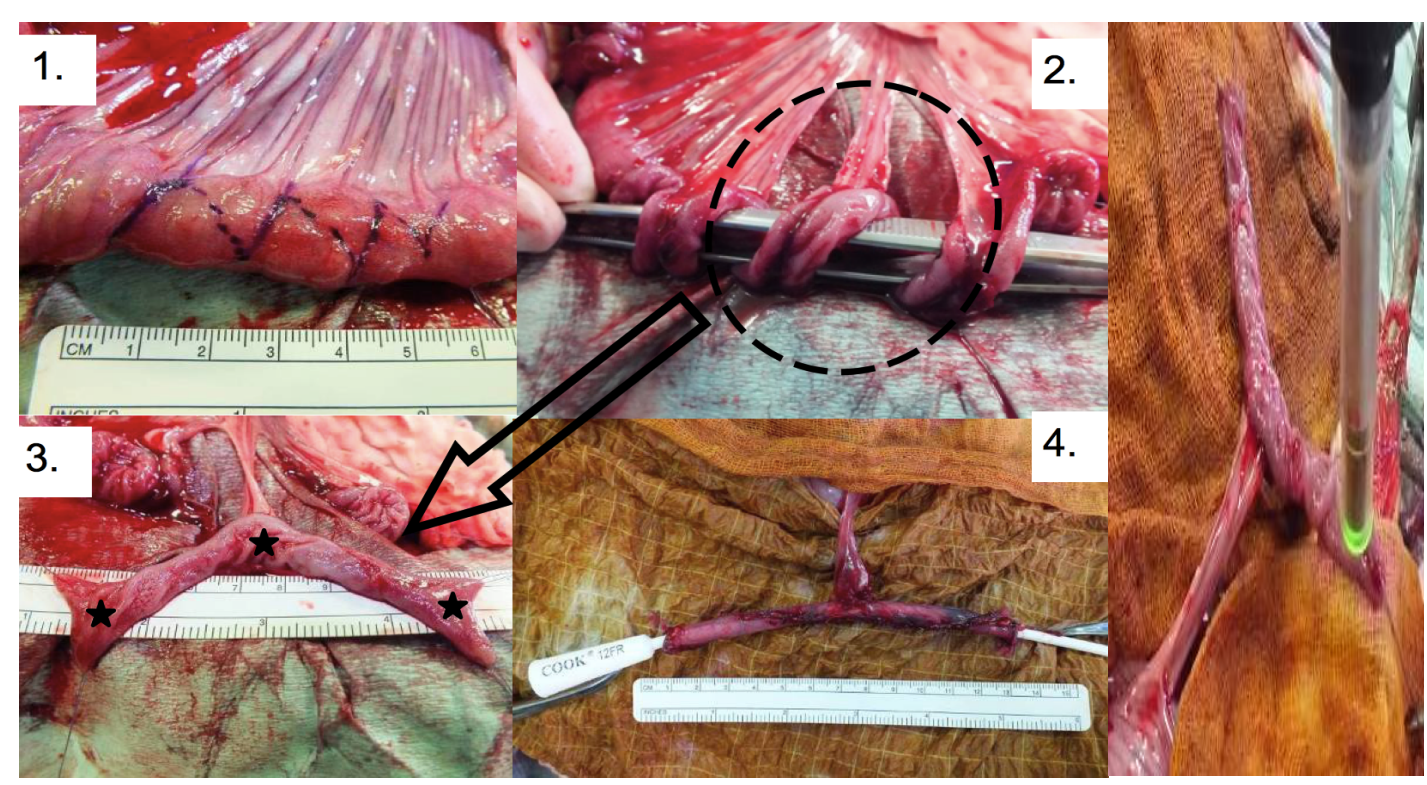

Figure 16.

The steps (1-4) of the creation of the catherisable channel and the measurement of the microcirculation

Four weeks later the animals were anaesthetized again and the catheterisable channels were examined and catheterised. Laparotomy was performed, the channels incised and mucosal microcirculation was recorded at the level of the bladder, adjacent to the abdominal wall and in the middle at the level of the mesentery. The channels were removed in one piece with the bladder for histological examination. Paraffinembedded cross sections of the channels at the level of the bladder, adjacent to the skin, in the middle and at the level of the mesentery were stained with hematoxylin eosin for conventional histology. 


\subsubsection{Statistical analysis}

The data analysis was performed with a statistical software package (SigmaStat for Windows; Jandel Scientific, Erkrath, Germany). The distribution of our experimental data was analysed by the Kolmogorov-Smirnov normality test. Failure of the normality test indicated nonparametric distribution of the data. Accordingly, we employed nonparametric statistical tests.

Differences between groups were analysed with Kruskal-Wallis one-way analysis of variance on ranks, followed by Dunn's method for pairwise multiple comparison in Study II. and V. Friedman repeated measures analysis of variance on ranks and MannWhitney Test were applied within groups in Study III. Wilcoxon rank sum test was applied for within group analysis. Differences between groups were analysed with Mann-Whitney test in Study IV.

In the Figures, median values and $75^{\text {th }}$ and $25^{\text {th }}$ percentiles are given; $p$ values $<0.05$ were considered significant.

\section{RESULTS}

\subsection{Clinical importance and efficacy of the bladder augmentation and continent cutaneous diversion}

A total of 32 salvage continence procedures were performed at a mean patient age of 6.3 years (SD 3.2). A total of 29 patients (91\%) are continent, 3 (9\%) are intermittently incontinent and none is continuously incontinent. One patient is continent after bladder augmentation (BA) using CIC. Two are continent and 1 is intermittently incontinent after BA and bladder neck repair (BNR) using urethral CIC. One is continent using urethral CIC through a cutaneous continent diversion (CCD) into a sigmoid bladder. A total of 19 children are continent after BNC, BA and CCD using CIC. However, 1 patient has required a repeated procedure because of a leaking stoma. A Monti tube was passed through the posterior rectus sheath and skin tunnel was constructed to lengthen the catheterizing channel. Four children are continent and are satisfied with a cutaneous urinary diversion. Two patients are continent and 2 are intermittently incontinent after a Mainz II pouch. 


\subsection{Intramural microcirculation of the ileal flap}

Examination of antimesenteric intramural vascular anastomoses: There was no significant difference in RBC velocity and the perfusion rate at the site of measurements between the Control Group and Group 1-2. (Figure 17).

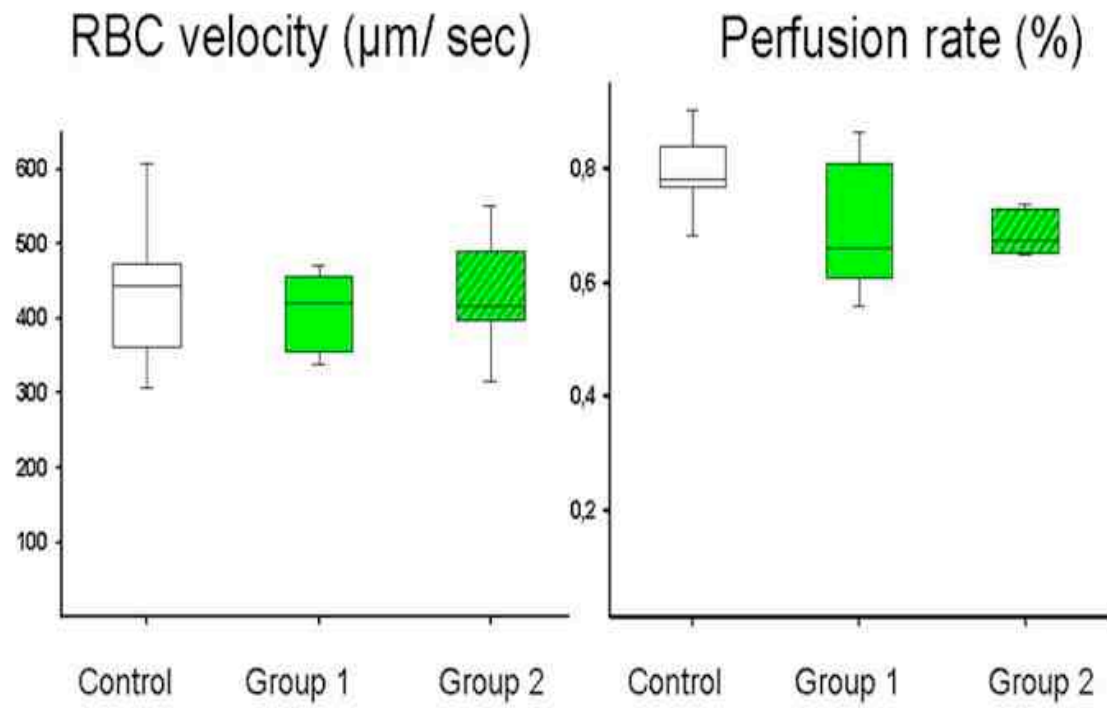

Figure 17.

$\mathrm{RBC}$ velocity and the perfusion rate in Control and Group1-2.

Examination of longitudinal intramural vascular anastomoses:

Continuous loop: No significant changes in the RBC velocity and perfusion rate have been seen after ligation of 2 vasa recta. However, the RBC velocity dropped significantly after ligation of 4 vasa recta, but the change in the perfusion rate remained non-significant. After ligation of 6 vasa recta both parameters approached the 0 level.

Loop with the free end: No significant changes in the RBC velocity and perfusion rate have been seen after ligation of 2 vasa recta. The RBC velocity diminished significantly after ligation of 4 vasa recta in a similar manner to the continuous loop. The reduction in perfusion rate was more expressed and significant too. After ligation of 6 vasa recta both parameters approached the 0 level (Figure 18). 

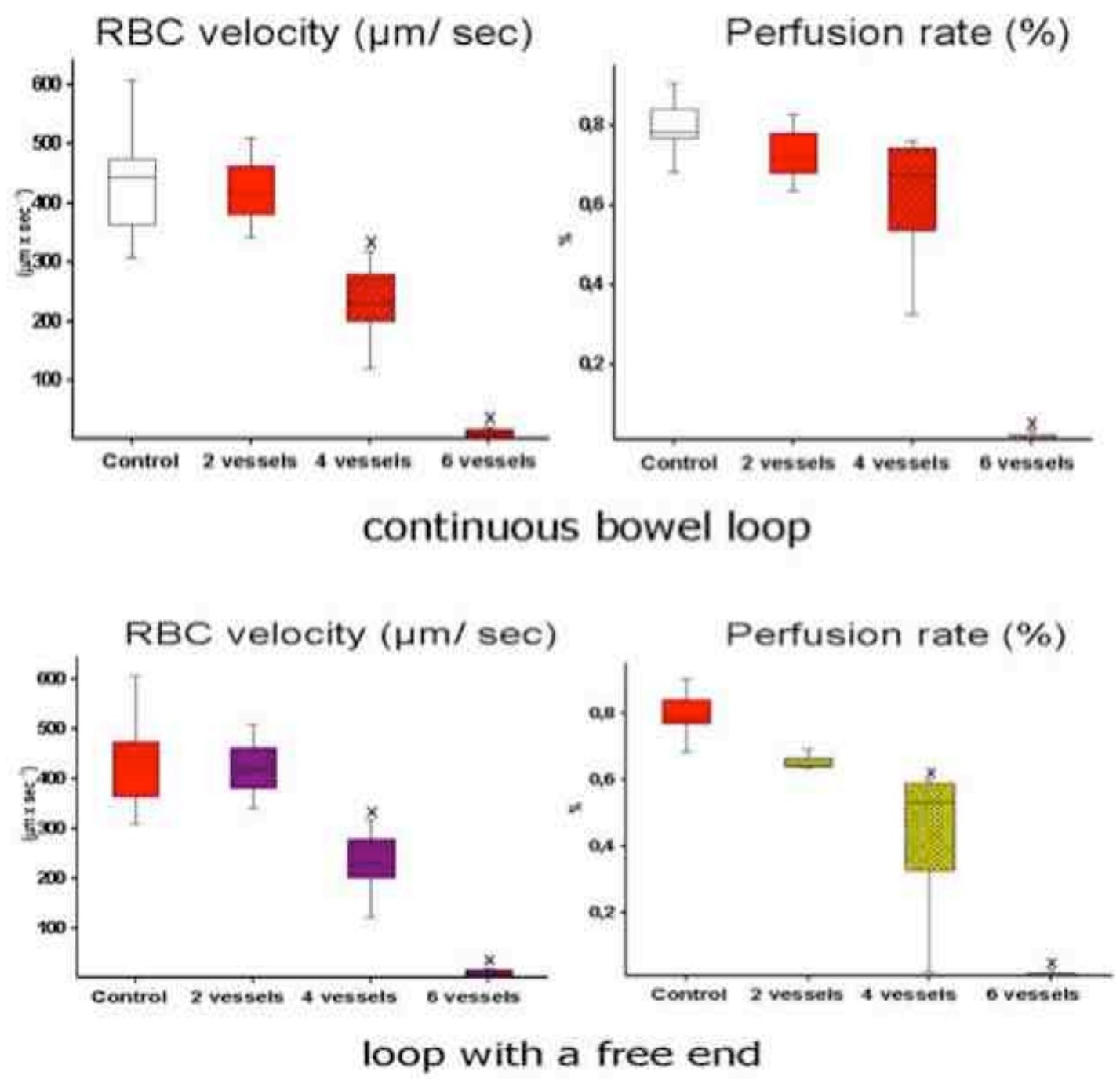

Figure 18.

$\mathrm{RBC}$ velocity and the perfusion rate after ligation of subsequent vasa recta

\subsection{New technique for augmentation if mesentery short}

Flap length: Paramesenteric detubularisation of the ileum resulted in mean $20.25 \pm$ $0.5 \mathrm{~mm}$ longer flap versus detubularisation along the mesenteric line. The difference in length reached $98 \%$ of the mean bowel width $(20.5 \pm 0.57 \mathrm{~mm})$ measured in the animals. Ligation of each VR further increased the length of both flaps. The length gain was different after each vessel, mean: $10.59 \pm 3.18 \mathrm{~mm}$ (Table 1.). 


\begin{tabular}{|c|c|c|c|c|c|c|}
\hline \multirow{2}{*}{\multicolumn{2}{|c|}{$\begin{array}{l}\text { Diameter of the bowel }(\mathrm{mm}) \\
\text { Number of ligated vessels }\end{array}$}} & \multicolumn{5}{|l|}{$20.5 \pm 0.57$} \\
\hline & & \multirow{2}{*}{$\begin{array}{l}0 \\
\text { Median:564.820 }\end{array}$} & \multirow{2}{*}{$\frac{1}{\text { Median:432.123 }}$} & \multirow{2}{*}{$\frac{2}{\text { Median:379.279* }}$} & \multirow{2}{*}{$\frac{3}{\text { Median:274.720* }}$} & \multirow{2}{*}{$\frac{4}{\text { Median: } 174.278}$} \\
\hline Control & $\operatorname{RBCV}\left(\mu \mathrm{m} \mathrm{s}^{-1}\right)$ & & & & & \\
\hline ileum flap & & 25\%: 521.250 & $25 \%: 396.510$ & $25 \%: 360.311$ & 25\%: 234.958 & 25\%: 115.194 \\
\hline & & $75 \%: 594.357$ & $75 \%: 467.285$ & $75 \%: 399.400$ & $75 \%: 290.250$ & $75 \%: 208.297$ \\
\hline & PR $(\%)$ & Median: 1.000 & Median: 1.000 & Median: $0.778^{*}$ & Median: $0.669^{*}$ & Median: $0.440^{*}$ \\
\hline & & 25\%: 0.995 & 25\%: 0.975 & 25\%: 0.694 & 25\%: 0.658 & 25\%: 0.351 \\
\hline & & $75 \%: 1.000$ & $75 \%: 1.000$ & $75 \%: 0.930$ & 75\%: 0.688 & $75 \%: 0.507$ \\
\hline & Length (mm) & 0 & $17.75 \pm 2.21$ & $28.75 \pm 7.58$ & $38.5 \pm 9.6$ & $45.5 \pm 9.25$ \\
\hline \multirow{7}{*}{$\begin{array}{l}\text { Alternative } \\
\text { ileum flap }\end{array}$} & $\operatorname{RBCV}\left(\mu \mathrm{m} \mathrm{s}^{-1}\right)$ & Median: 584.238 & Median: 392.895 & Median: $264.854^{*}$ & Median: $176.225^{*}$ & Median: 65.658 \\
\hline & & $25 \%: 549.072$ & $25 \%: 353.378$ & $25 \%: 252.373$ & $25 \%: 166.033$ & $25 \%: 40.326$ \\
\hline & & $75 \%: 625.915$ & $75 \%: 415.365$ & $75 \%: 287.159$ & $75 \%: 185.324$ & $75 \%: 80.235$ \\
\hline & PR (\%) & Median: 1.000 & Median: 0.994 & Median: 0.901 & Median: $0.650^{*}$ & Median: 0.299* \\
\hline & & $25 \%: 0.995$ & 25\%: 0.956 & $25 \%: 0.821$ & $25 \%: 0.499$ & 25\%: 0.184 \\
\hline & & $75 \%: 1.005$ & $75 \%: 1.000$ & $75 \%: 0.935$ & $75 \%: 0.671$ & $75 \%: 0.357$ \\
\hline & Length (mm) & $20.25 \pm 0.5$ & $30.75 \pm 9.74$ & $39.75 \pm 11.98$ & $48.5 \pm 13.02$ & $59.5 \pm 11.67$ \\
\hline
\end{tabular}

Table 1.

This table summarizes the microcirculatory parameters and the length of the flaps after consecutive ligation of vasa recta

Microcirculation: The statistical analysis did not show significant difference in the red blood cell velocity (RBCV) and perfusion rate (PR) between the antimeseterically detubularised ileal flaps and the paramesenterical detubularised flaps.

Ligation of VR up to 1 vessel did not affect RBCV and PR compared to the baseline values in both groups. Ligation of 2, 3 and 4 vessels gradually decrease RBCV and PR in both groups significantly, however, after ligation of the $4^{\text {th }}$ vessel still marked circulation was seen (Figure 19,20.). 

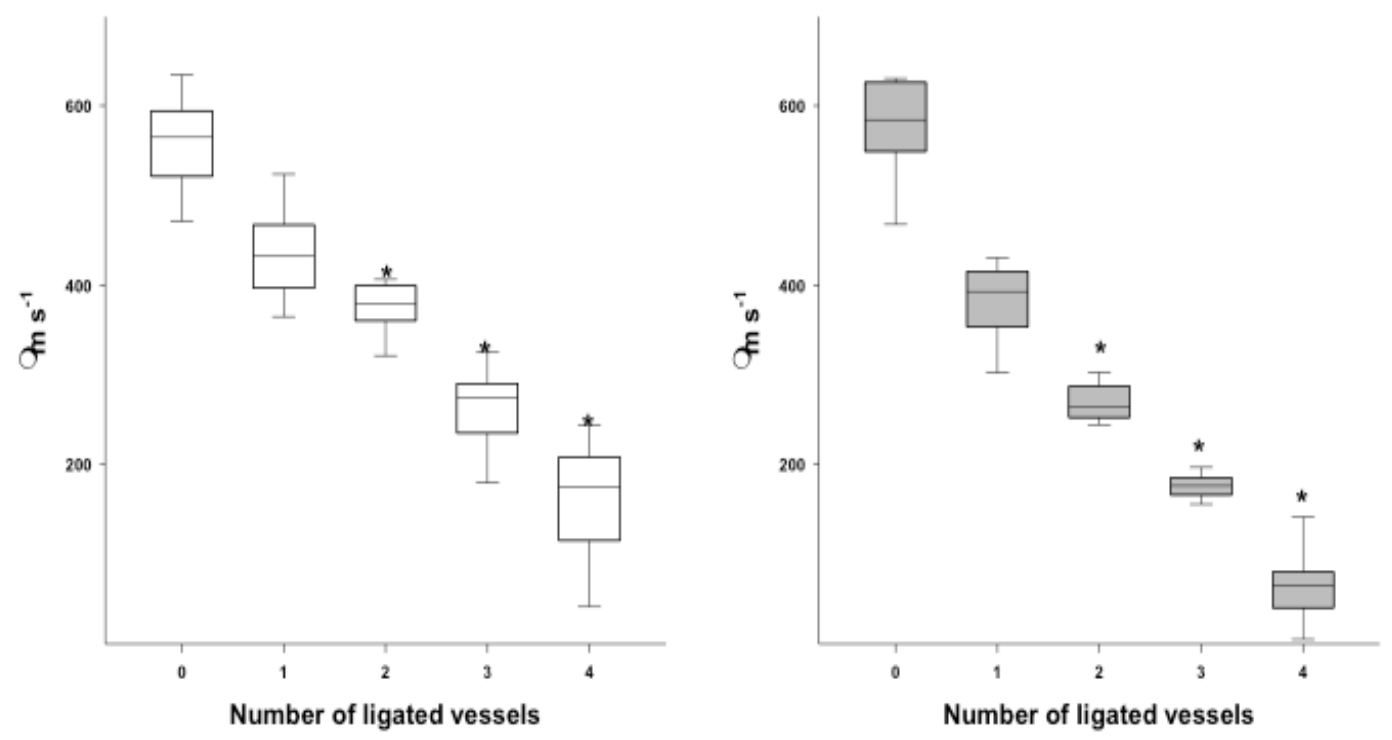

${ }^{*} \mathrm{p}<0.05$ within group and baseline value (Friedman Repeated Measures Analysis)

Figure 19.

Changes in red blood cell velocity in the normal and in the alternative flap: The plots demonstrate the median values and the $25^{\text {th }}$ (lower whisker) and $75^{\text {th }}$ (upper whisker) percentiles; ${ }^{*} p<0.05$ within groups $v s$ baseline values.
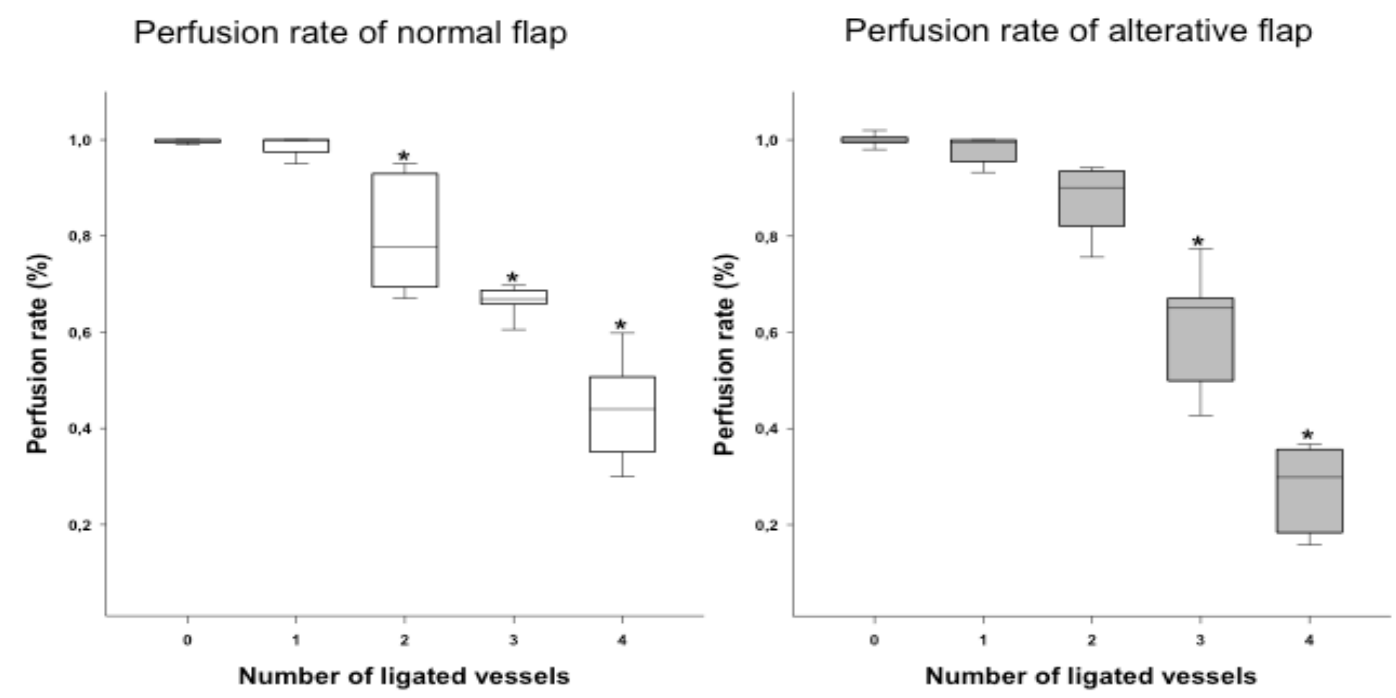

${ }^{*} \mathrm{p}<0.05$ within group and baseline value (Friedman Repeated Measures Analysis)

Figure 20.

Changes in perfusion rate in the normal and in the alternative flap: The plots demonstrate the median values and the $25^{\text {th }}$ (lower whisker) and $75^{\text {th }}$ (upper whisker) percentiles;

$* p<0.05$ within groups $v s$. baseline values. 
Bladder augmentation: All animals recovered after the clam ileocystoplasty performed with paramesenterically detubularised ileum flap. There was no urine leakage or suture break down found at the autopsy (Figure 21.).

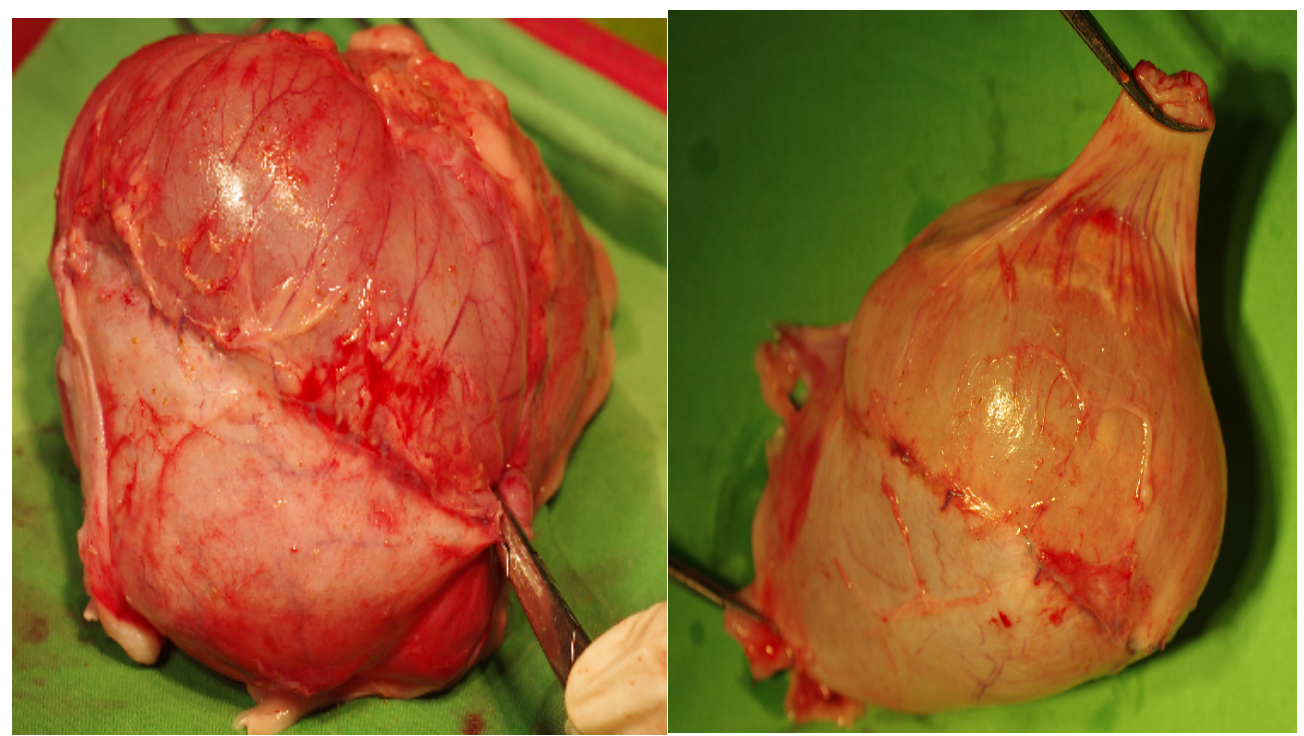

Figure 21.

The bladder augmented with the alternative flap after autopsy.

Note no contraction of the ileum flap seen.

Histology: The hematoxylin eosin staining confirmed viable bowel flaps anastomosed to the bladder. The bowel mucosa was not atrophic, no fibrosis seen in the bowel flap (Figure 26.).

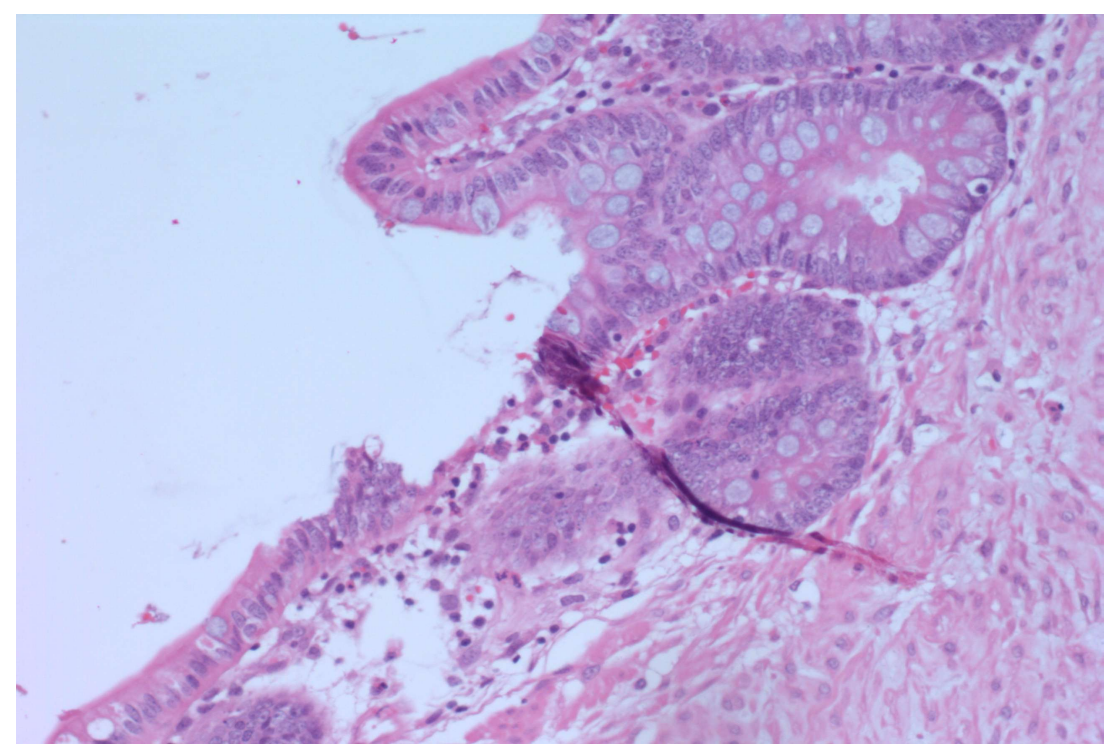

Figure 22.

The fusion of the bladder and bowel mucosa in the augmented bladder with the alternative flap. 


\subsection{Effect of mucosectomy on flap microcirculation and flap contraction}

The mean width of the detubularised ileum was $37 \pm 1 \mathrm{~mm}$ at pre-augmentation in the animals. Significant reductions in RBCV and PR were detected after mucosectomy in both mucosectomy groups (Figure 23).
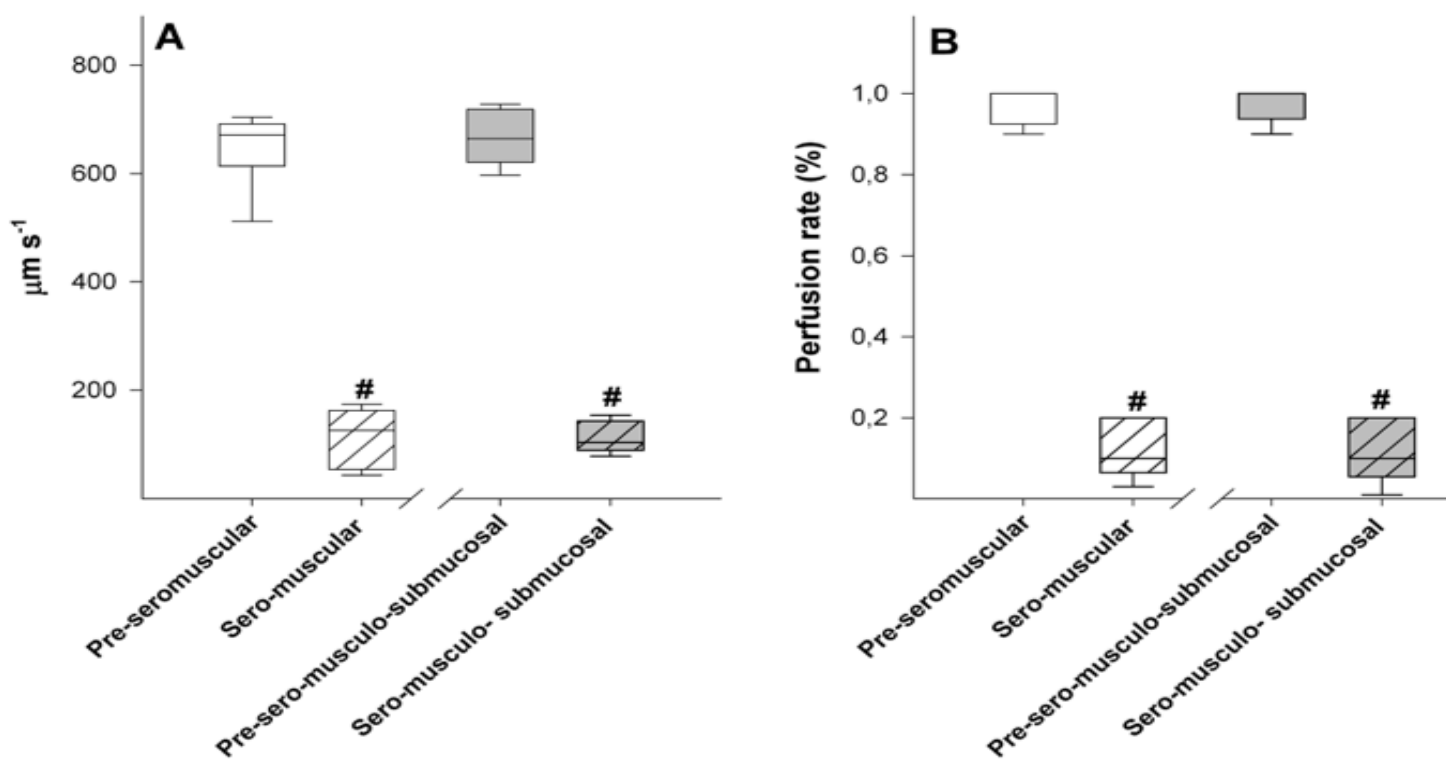

Figure 23.

RBCV and PR were detected after mucosectomy

The animals recovered very quickly after the operation. They were kept on liquid food for 3-4 days than fed normally. They were not lethargic no loss off appetite was observed and their wound healed well. They passed the catheter in 5-7 days. No complication like peritonitis, ascites was seen. At the autopsy no perforation or necrosis was seen. The average width of the ileum measured after autopsy was $16 \pm 2$ $\mathrm{mm}$ in the sero-muscular group, and $20 \pm 2 \mathrm{~mm}$ in the sero-musculo-submucosal group (Table 2.).

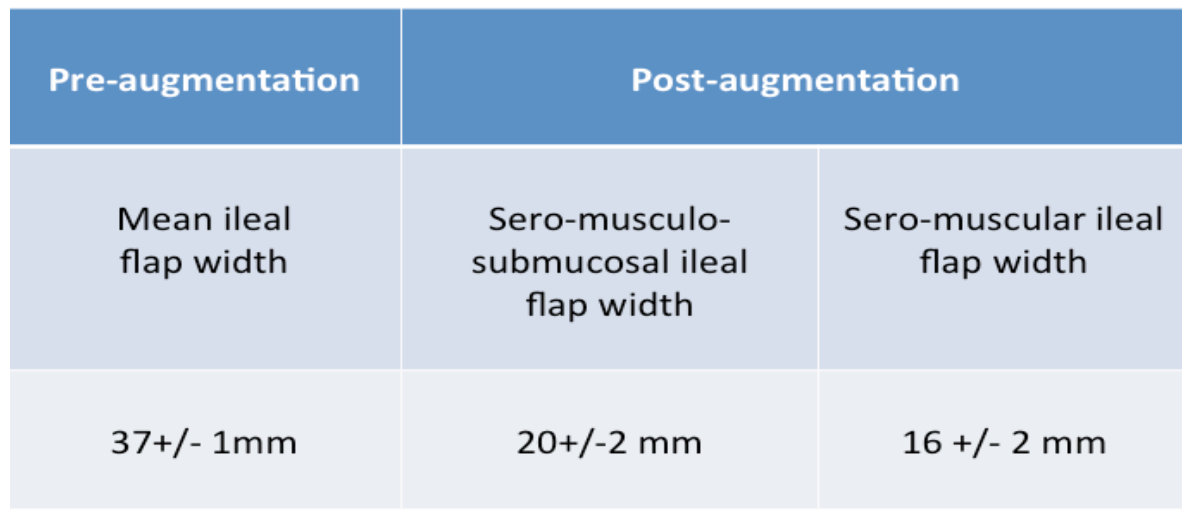

Table 2.

The width of the bowel flaps pre- and postaugmentation 
The omentum was found firmly attached to the ileal flaps; however, significant $(p<0.05)$ contraction of the flaps had developed in both groups (Figure 24.).

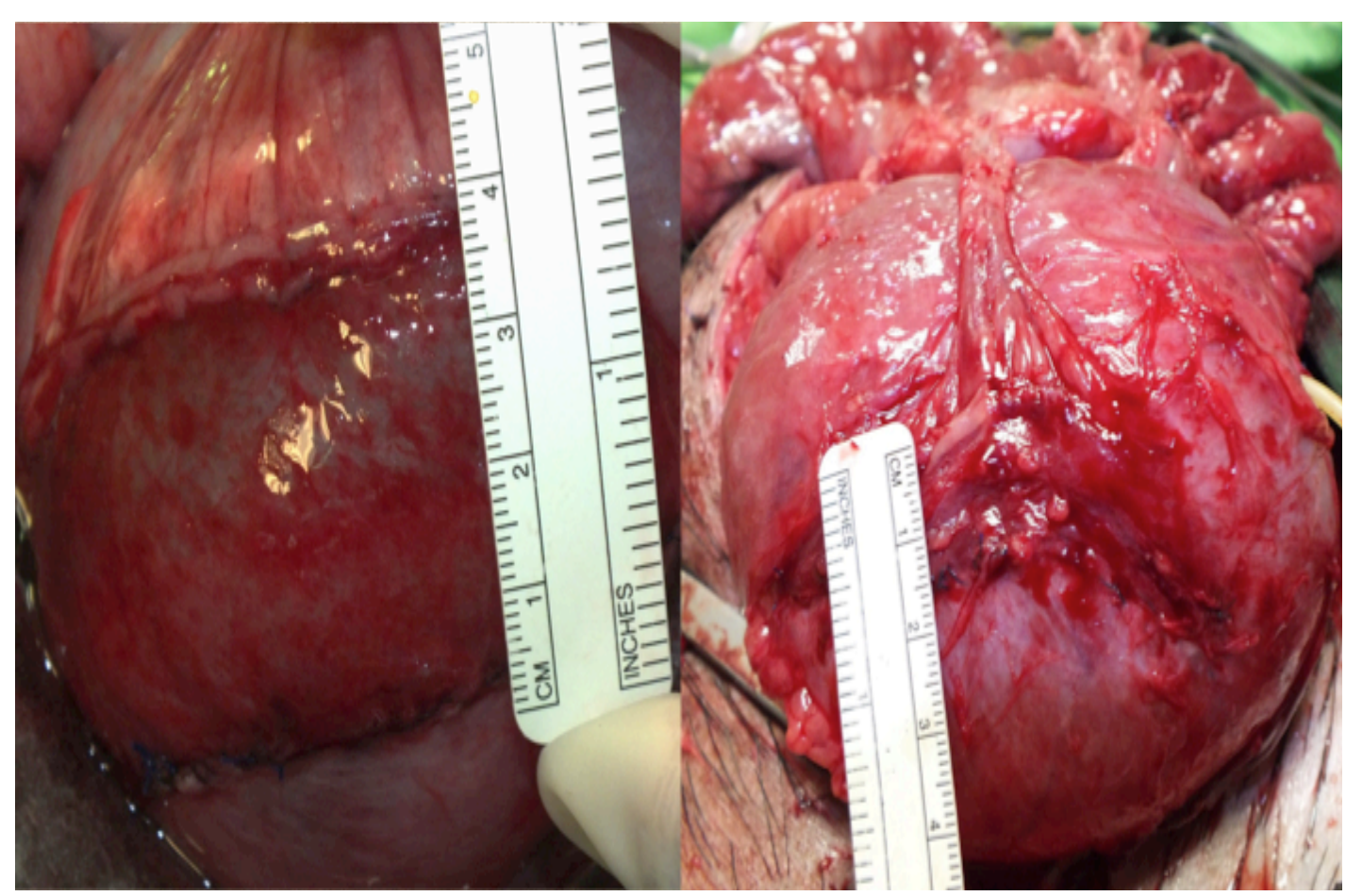

Figure 24.

Left: The flap width at the reconstruction Right: The flap width at the autopsy

\subsection{New concept to create long and straight continent urinary stomas}

The mean width of the ileum was $20.5 \pm 0.57 \mathrm{~mm}$. We were able to create straight spiral channels over a $12 \mathrm{~F}$ Foley catheter with the mean length of $100 \pm 26.4 \mathrm{~mm}$ (Figure 16/4.). The RBCV dropped $17 \%$ at the edges of the bowel strip after the spiral incision to median 397,171 $\mu \mathrm{m} / \mathrm{s}(25 \%: 322,016,75 \%: 444,652)$. This difference was statistically significant compared to control values, Median: 478,846 $\mu \mathrm{m} / \mathrm{s}(25 \%$ : 450,479 75\%:500,611), however, no significant difference was found 4 weeks later, Median: 458,000 $\mu \mathrm{m} / \mathrm{s}$ ( 25\%: 439,000 , 75\%: 496,250). Similarly the PR dropped 8.3 $\%(\mathrm{p}<0.05)$ at the edges of the bowel strip after the spiral incision from 1.000 (25\%:0.982, 75\%:1.000) to $0.917(25 \%: 0.873,75 \%: 0.993)$, but recovered after 4 weeks to $0.980(25 \%: 0.950,75 \%: 1.000)$ (Figure 25). 

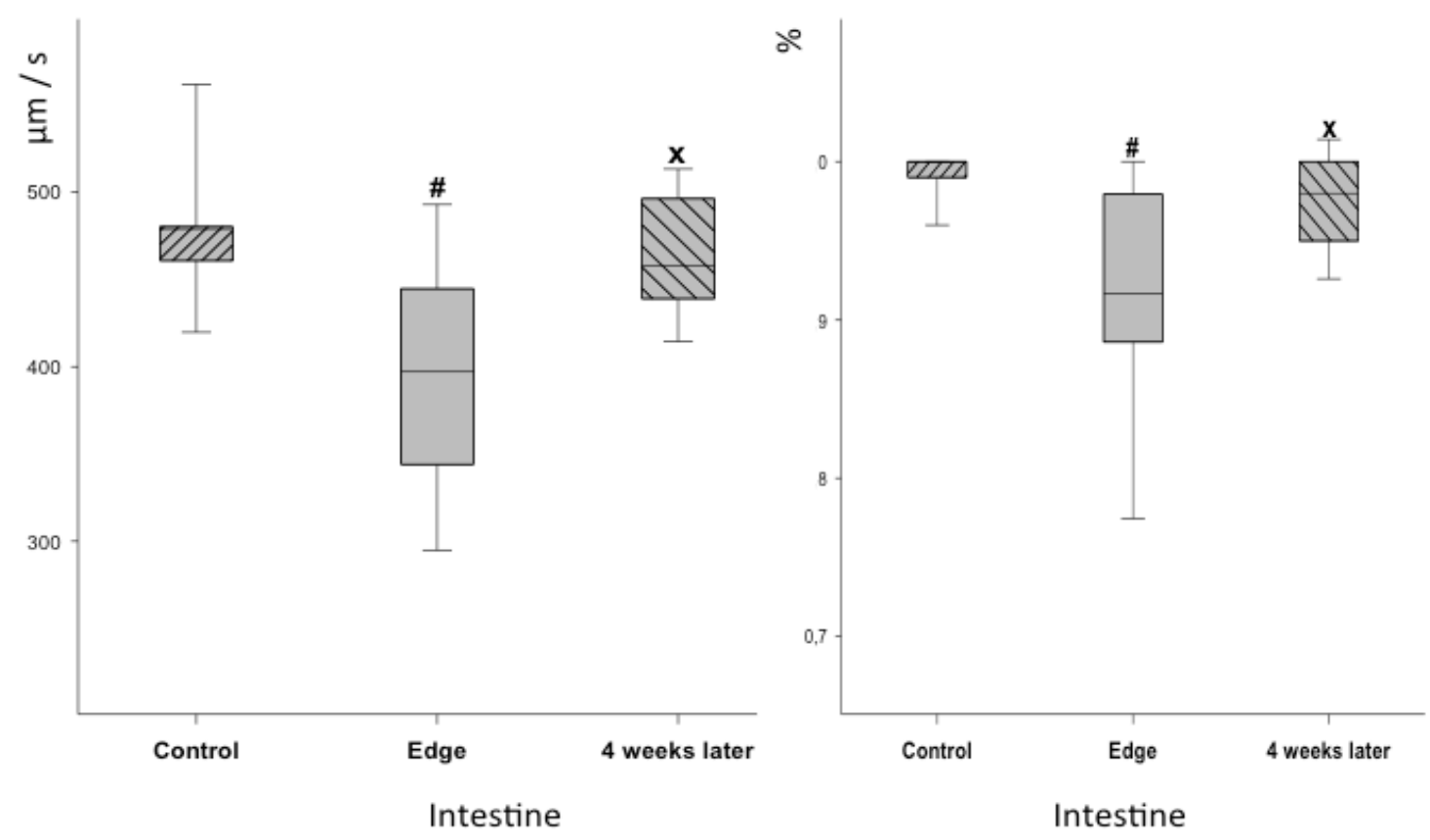

Figure 25 .

Microcirculation of the bowel strip after the procedure and 4 weeks later

The Malecoth catheters were lost within 2 weeks. At the level of the epidermis the opening of the channels were found to be narrow, but after some dilatation they became patent and easily catheterisable. All implanted channels remained viable and straight. The histology showed no necrosis of mucosa and muscle layers either at the skin or bladder level (Figure 26-27.). 


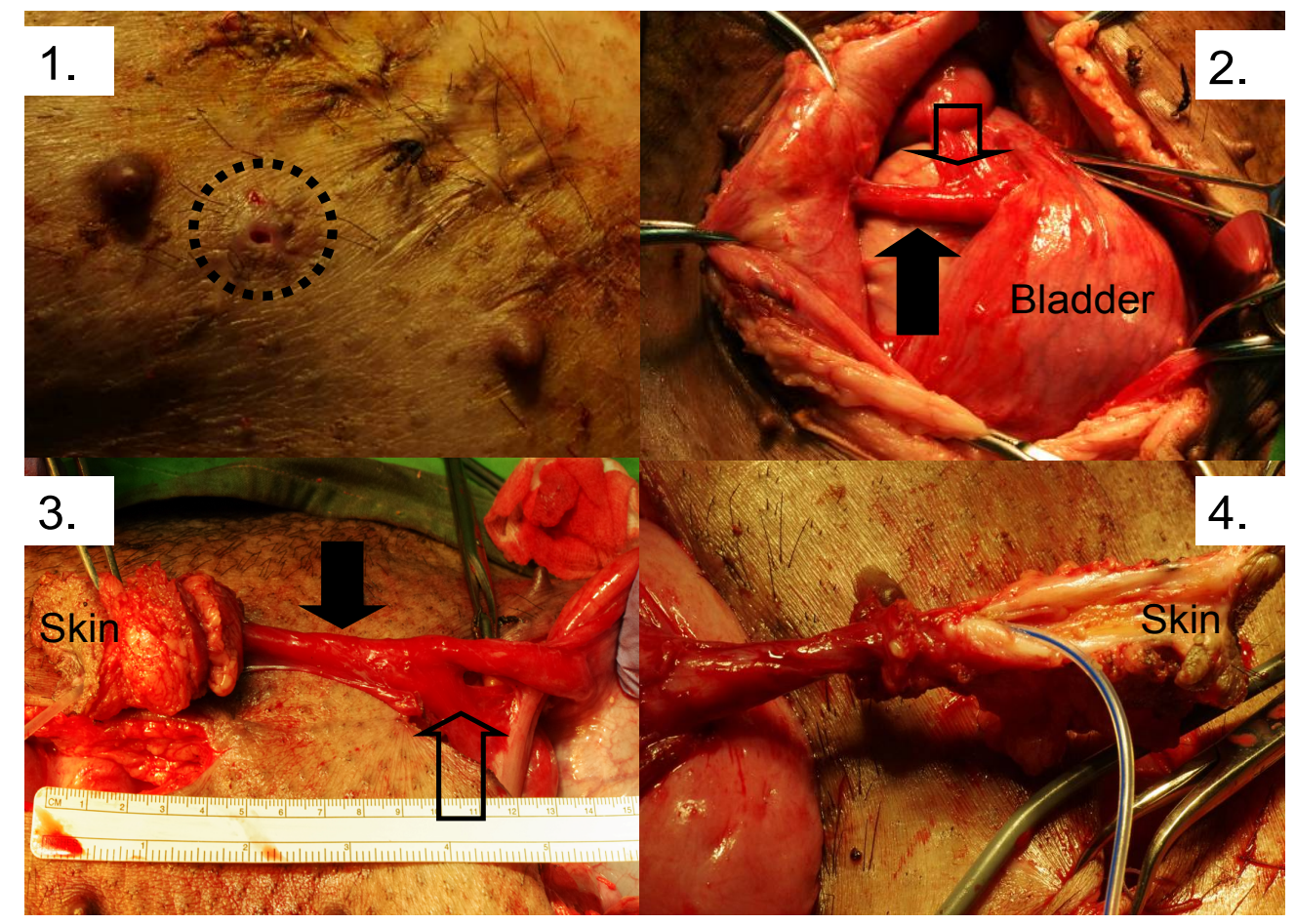

Figure 26.

The cannels narrowed at the skin level, but were patent and viable below.

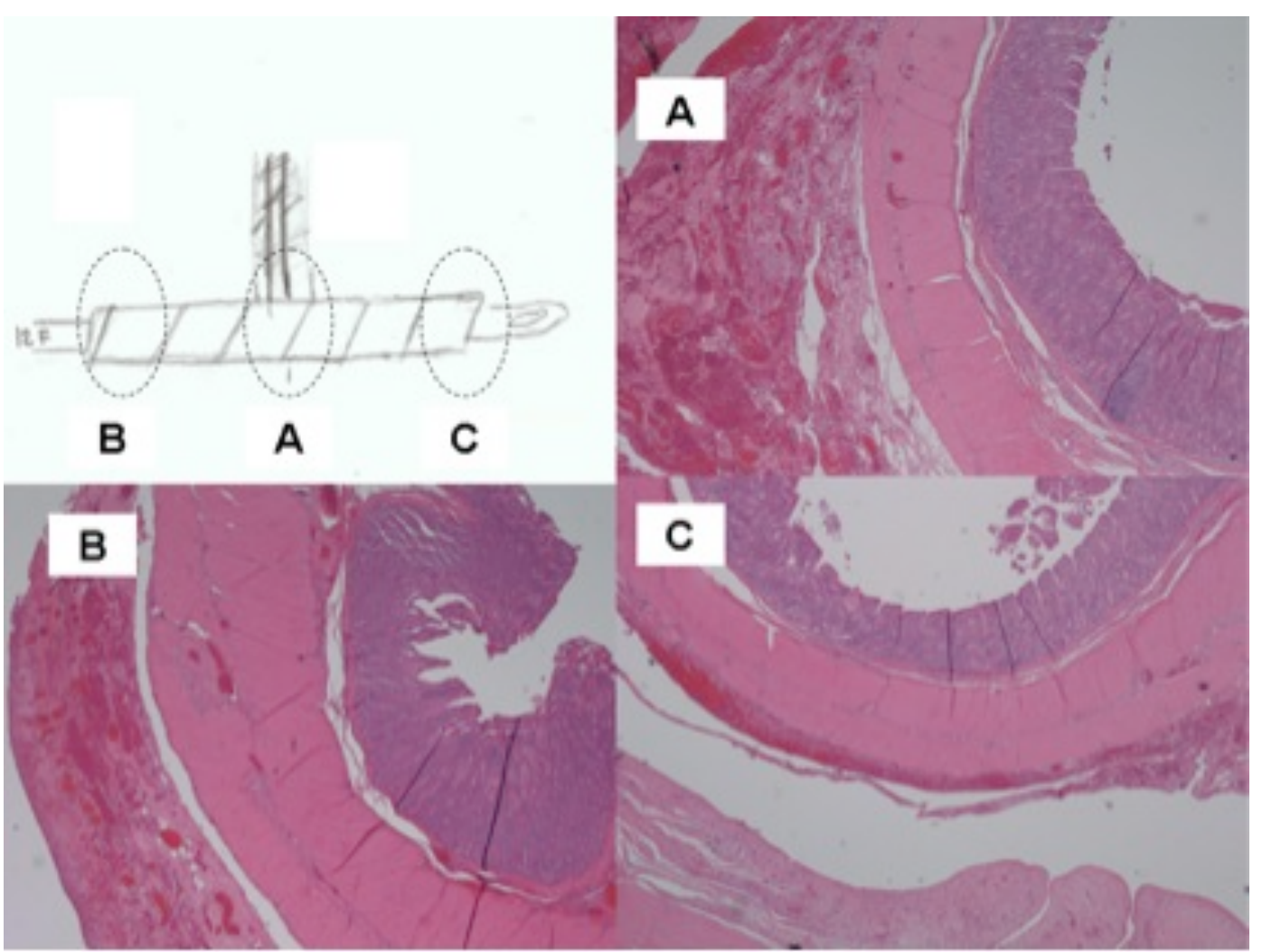

Figure 27.

HE staining showed no atrophy or fibrosis at the edges of the channel compared to the middle. 


\section{DISCUSSION}

\subsection{Clinical importance and efficacy of the bladder augmentation and continent cutaneous diversion}

Successful primary anatomical closure of bladder, posterior urethra, abdominal wall and pelvic bones is the first step towards good bladder volume in children born with bladder exstrophy. Pelvic osteotomy allows a tension-free abdominal closure that consistently reduces the chance of breakdown (47). In this series all of our patients underwent posterior pelvic osteotomy performed by our urology team. With the creation of the Manchester Exstrophy Unit in 2000 the exstrophy complex has been managed by a multidisciplinary team that now includes a pediatric orthopedic surgeon, such that we now also offer anterior iliac pelvic osteotomy with insertion of an external pelvic fixator (47). It is believed that this approach allows for better pelvic mobilization at the time of the bladder and abdominal wall closure, and improves the long-term stability of the reconstructed pubic symphysis (48).

Gearhart et al reported that patients undergoing 2 or more attempts at bladder closure fail to achieve satisfactory bladder capacity and are not suitable for bladder neck reconstruction (49). Three of the 21 patients treated elsewhere required a second attempt at bladder closure because of wound breakdown, which compromised the bladder capacity.

Adequate bladder capacity failed to develop in some patients who underwent successful primary bladder closure. We believe that adequate outlet resistance following primary bladder neck closure is fundamental to achieve good bladder capacity. This outcome must be balanced against the need to avoid too tight a closure so as not to compromise the upper urinary tracts. Even in patients with adequate bladder capacity upper urinary tract dilatation represents an insidious complication after reconstruction for bladder exstrophy. Regular ultrasound monitoring is essential for early diagnosis, and CIC should be commenced in patients exhibiting increasing hydronephrosis. Anticholinergic drugs may enhance the benefits of CIC but control trials are necessary to evaluate their impact on patients with bladder exstrophy. 
Interestingly, Gearhart and Jeffs have observed that urethroplasty in boys with bladder exstrophy increases urethral resistance and subsequently induces bladder growth (50.). At our unit we now perform epispadias repair at age 6 months, with preliminary results demonstrating a marked improvement in bladder capacity, seemingly confirming the Baltimore experience.

Bladder neck reconstruction is the next step toward continence for the majority of patients who continue to be wet after primary bladder and urethral reconstruction. Six patients in our series ( 3 referred) had a failed bladder neck repair and therefore proceeded to salvage continence surgery. The 3 children who underwent bladder neck reconstruction elsewhere suffered from frequency and intermittent incontinence, which we believe were due to inadequate bladder capacity. The normal expected bladder capacity at age 5 years, the age when we start considering continence surgery, is $180 \mathrm{cc}$ (51) but similar values develop in few patients with exstrophy. We do not perform bladder neck repair in patients with a capacity of less than $85 \mathrm{cc}$ (half expected capacity), since the literature suggests that bladder neck repair offers more reliable results when performed above this value (52) One of our patients had severe bladder outlet obstruction following bladder neck repair, and 2 remained intermittently incontinent despite an initial capacity of 90 to $120 \mathrm{cc}$. The concentration of patients with exstrophy at our hospital, now a dedicated referral center, has led to greater success with bladder neck repair. We emphasize the importance of working with motivated children and families, (52) and confirm that multiple attempts at bladder neck repair are not helpful $(53,54$.).

Four patients who had undergone previous multiple operations underwent cutaneous urinary diversion and are satisfied with that choice. Cutaneous urinary diversion (non continent ileal conduit) should be considered as an alternative to continent cutaneous diversion, particularly if the expected compliance to CIC is likely to be poor. Cutaneous urinary diversion is easily managed, reduces the risks associated with continent stomas and bladder augmentation (urinary tract infection, stone formation, malignancy), and can be converted to bladder augmentation and continent cutaneous diversion later in life. Our limited experience with the Mainz II pouch has not been satisfactory, and we do not regularly offer it. Furthermore, we remain concerned at the reported suggestion of a significant incidence of long-term malignancy (55). 
The preoperative social and psychological assessment of the incontinent child and his/her family is essential in choosing surgical treatment. We wait until the patient is at least 5 years old before considering any continence surgery, so he/she can express his/her own view on the matter. The selection between bladder neck repair and the different forms of urinary diversion is mainly based on bladder capacity but the expectation and motivation of the patient and his/her family also has a vital role.

\subsection{Intramural microcirculation of the ileal flap}

Anatomists have extensively studied intestinal circulation in the past, but several controversies have been left unanswered. According to Jonnesco (1912) the vasa recta of the bowel divide into two equal branches, which encircle the gut to anastomose with each other at the antimesenteric border (24). Eisberg (1924) and Noer (1943) claimed that there are numerous anastomoses between the smaller branches of adjacent vasa recta in the bowel wall. Cokkinis (1930) observed that the intramural vessels ramify in an arborescent manner, but he found no evidence for anastomoses of the contiguous vessels. It has been reported that the subperitoneal ramification stops short a little distance from the antimesenteric border and a clear longitudinal band free from visible vessels is present in all specimens (25-27). Doran studying the upper jejunum in human post mortem specimens found communications only of the arteries of the calibre of the primary branches of the vasa recta. Neither the smaller arteries, nor of those arising from the sides of the larger vessels showed communications. The position of these anastomoses was found irregular and not conforming to any set pattern (27).

In our study, we demonstrated undisturbed microcirculation far beyond the antimesenteric line right up to the mesenteric line in a bowel segment, which was detubularised next to the mesentery. In the clinical practice it means that at detubularisation the surgeon does not to need follow the antimesenteric line, it can be done anywhere else along the circumference safely without compromising microcirculation. This is in accordance with our experience with the SILT technique we recently developed. In this procedure the intestine is incised along a spiral line. This technique proved viable in animal model and in clinical practice (44-46). 
In clinical practice, paramesenteric detubularisation has only previously been used in a modified Monti procedure to create a catheterisable channel for augmented bladder (20). The aim of the paramesenteric detubulurasation was to leave sufficient length mesentery free end of the channel to allow easy implantation in the bladder in an antireflux manner to achieve continence. There were no major concerns reported regarding viability of these channels.

Urologists have made several attempts to create a reliable, but "mucus free" bladder augmentation, but this still remains unsolved. In an experimental animal study "mucus free" bladder augmentation has been performed with paramesenterically detubularised reverse sero-muscular bowel flaps. All the flaps fibrotised and contracted within a few weeks (39). It was not clear whether the paramesenteric detubularisation or the mucosectomy was responsible and the technique was abandoned. It is now clear the paramesenteric detubularisation cannot be claimed to be the reason for this.

Detubularisation of the ileum next to the mesentery rather than at the antimesenteric line may allow us to create longer reaching vascularised ileal flaps for bladder augmentation during clam ileocystoplasty, which may be particularly useful if the mesentery is short. This could be also useful for vaginal replacement in cloacal anomalies when the bowel segment needs to reach to the perineum.

To examine the efficacy of the longitudinal anastomoses the antimesenteric anastomoses were cut. The bowel wall received perfusion only through the neighbouring longitudinal anastomoses at the site of the measurements after the corresponding vasa recta had been cut. On the continuous loop the blood supply came from both sides, while on the loop with the free end only from one side.

The fact that ligation of a 2 vasa recta did not affect the microcirculation is a clear evidence of the presence of functioning longitudinal intramural anastomoses. The efficacy of these anastomoses was limited up to ligation of 4 vessels. We expected the loop with the free end to be more sensitive to vasa recta ligation having anastomoses only from one side, but we did not find a marked difference between the two loops. The reduction of the RBC velocity was very similar, only the perfusion rate dropped 
more rapidly in the loop with the free end. These findings are not really surprising and justify the present surgical practice that only very short bowel segment detached from mesentery can be used safely

\subsection{New technique for augmentation if mesentery short}

Tension-free bowel anastomosis and well-perfused tissue are essential when bowel segments are used in reconstructive urological procedures. Short mesentery due to previous surgeries, peritonitis, peritoneal dialysis and ventriculo-peritoneal shunt may complicate these procedures (1-3). Levin used the "stepladder incision" technique and gained up to $30 \mathrm{~mm}$ of additional length for urological reconstruction without complication (5). This is $80 \%$ of the diameter of an adult human ileum $(37.5 \mathrm{~mm})$ according to Gray's anatomy textbook (56). The paramesenteric detubularisation of the ileum resulted in $20.25 \pm 0.5 \mathrm{~mm}$ longer alternative flaps in the pigs, this reached $98 \%$ of the diameter of the bowel $(20.5 \pm 0.57 \mathrm{~mm})$. These results suggest that paramesenteric detubularisation is more effective than Levin's procedure. Further benefit could be achieved if both techniques were combined. Intravital microscopy showed no significant difference in the velocity of the circulating erythrocytes and the perfusion rate at the edge of the alternative ileal flaps. All 5 operated animals survived without suture break down or urine leakage and the histology did not reveal necrosis at the anastomosis line. These findings demonstrate that paramesenteric detubularisation is safe and does not compromise the microcirculation of the ileum and wound healing.

According to the observation of Eisberg and Noer $(25,57)$, we expected that ligation of some VR did not alter microcirculation. Ligation of 1 VR did not alter the RBCV and PR significantly either in the control or in the AF groups. This may suggest that paramesenteric detubularisation and ligation of 1 VR could be combined to gain more length. In clinical practice however, due to the possible anatomical variations, it could be difficult to assess the limitation of the VR ligation unless precise intraoperative intravital microscopy is performed. Although there are no exact data available in the literature regarding the values of $\mathrm{RBCV}$ and $\mathrm{PR}$ required for uneventful wound healing, in this study we hypothesized that any compromise in the microcirculation may result in complications. 


\subsection{Effect of mucosectomy on flap microcirculation and flap contraction}

With the spread of minimally invasive endoscopic submucosal dissection (ESD) technique for removal of gastrointestinal mucosal malignancies, there is more indirect evidence that esophageal, gastric and colorectal stricture occurs after surgical manipulation of the submucosa, especially after ESD of large lateral spreading tumors occupying $75 \%$ of the lumen $(58,59)$. Further evidence of contraction after mucosaectomy, is the cuff stenosis which occurs after the Soave endorectal pull through procedure for Hirschsprung disease, where during the procedure submucosal dissection is carried out (60). Indeed it is general practice to incise the residual seromuscular cuff, such is the regularity with which cuff contraction occurs.

In this study we used intravital videomicroscopy to monitor the microcirculation of the sero-muscular ileal flaps in real time after mucosectomy. The two parameters (the velocity of the circulating red blood cells and the ratio of the open and closed capillaries) measured are widely accepted parameters to represent the patency of microcirculation $(31,32)$. These findings clearly indicate that mucosectomy with or without removal of the submucosa has major impact on the microcirculation of the residual flap. The incomplete circulatory cessation explains why acute necrosis and perforation was not present and why histology with light microscopy did not reveal thrombotic vessels in previous studies.

It has been observed that the branches of the vasa recta encircle the intestine and penetrate the muscle layers and form an arterial plexus within the submucosa. The vessels supplying the mucosal and muscular layers of the gastrointestinal tract originate from this plexus (61). We propose that mucosectomy may disrupt fine vascular circuits within the intestine and the blood supply of the mucosectomised bowel may rely only on residual vessels originating directly from vasa recta. However, temporary ischemia-reperfusion caused by mucosectomy cannot be ruled out in the background.

It could be postulated that exposure of the serosa to urine could be responsible for contraction of the flaps and we should have used a control group with intact reversed flaps with no mucosectomy to assess this question. In a dog experiment, However, 
Cheng et al clearly showed that the serosal surface of the reversed ileal flaps become epithelised by urothelium and intact (full thickness) reversed flaps did not contract (39).

The application of intact (full thickness) reversed flaps is not ideal either, because the mucus produced by the intact flaps inside the peritoneum may result in intraabdominal mucocele formation. Cheng et. Al reported moderate amounts of mucus pooled intra-abdominally one month after surgery in a dog (39). We also found a large mucocele perforating to the augmented bladder in one pig with full thickness (no mucosectomy) reverse ileal flap augmentation. The ileum flap however, remained wide, i.e. no contraction seen. To comply with our ethical approval (to keep the number of animals sacrificed as low as possible) we did not use more animals for full thickness reverse flap augmentation. Splints may have prevented the flap contraction, but the pig bladders in our study were not drained for a long time, the animals lost their urethral catheter within 7 postoperative days.

The omentum is known to be highly vascularized with microvascular endothelial cells and is composed mainly of adipocytes that produce an enormously high level of vascular endothelial growth factor (40). Omentopexy has been used to facilitate revascularisation of trachea grafts, myocardium and even brain (41-43), However, in our experiment it failed to recover the mucosectomised flaps. Revascularisation from the omentum may require a longer period of time to occur and should precede the ischaemic event, which is obviously not possible in this situation.

\subsection{New concept to create long and straight continent urinary stomas}

The concept of Spiral Intestinal Lengthening and Tailoring (SILT) i.e. refashioning normal caliber bowel tube to a narrower shape in order to create an alternative Mitrofanoff channel was tested in this study.

The channel length achieved by SILT in this experiment $(100 \pm 26.4 \mathrm{~mm})$ is outstanding, it exceeds the calculated length of the Monti technique (bowel width $\mathrm{x} 2$ ) and the double Monti and the Casale procedure (bowel width x 4) (Figure 3).

Theoretically, catheterisable channels could be designed by determining the length of the channel required and calculating backward the length of segment needed to harvest based on percent increase in length and tailoring. In our model we 
experienced $55 \%$ lengthening and $80 \%$ tailoring, this is in accordance with the linear regression between the lengthening and tailoring in SILT we reported earlier (44). However, in this model it become clear that 2 full (360 degree) spiral cuts, one proximal and one distal to the mesenteric attachment selected, provides a longer channel compared to present techniques without bulky mesentery at the end of the channels for easy implantation. The length of the harvested bowel segment is rather determined by the width of the mesentery selected. This measures $15-20 \mathrm{~mm}$ at the Monti or Casale procedures and it is usually enough to incorporate a strong branch of the mesenteric vessel. The mesentery in our model was designed to be $15 \mathrm{~mm}$ wide, however, a wider mesentery strip could have been easily used. This would have resulted in stronger mesentery and would have further increased the channel length, however, beyond a certain extent may have complicated spiral reconstruction. It is more difficult to reconstruct a wide bowel strip to a narrow (12 F) spiral channel.

The minimum length of the harvested segment should be 3 times the width of mesentery we select. In our model this was $45 \mathrm{~mm}$. In the study however, 60-80 $\mathrm{mm}$ long segments were harvested to facilitate tissue handling and half of them was discarded. We believe loosing of 40-50 $\mathrm{mm}$ bowel length is not significant.

Extrapolating our results to a human ileum, which is approximately $55 \mathrm{~mm}$ wide $(\pi \times$ diameter / 2) (56) this creates a spiral channel longer than $220 \mathrm{~mm}$. We believe a channel longer than this is hardly ever required.

A transient alteration in the microcirculation of the bowel immediately after the procedure was experienced. Interestingly, after using SILT in a model of short bowel syndrome, changes in the microcirculation after spiral cut were not recorded (44). This could be explained with the fact that for the alternative Mitrofanoff the bowel was disconnected next to the vasa recta, while in the short bowel model the bowel remained continuous. Furthermore in the short bowel model dilated (40-50 mm wide) bowel loop was refashioned and the bowel strip after the spiral incision was much wider $(30-40 \mathrm{~mm})$ compared to the present experiment where the spiral incision resulted in $15 \mathrm{~mm}$ wide bowel strip. The tissue handling could have simply had an effect on the microcirculation, however, this was performed with care and the bowel was rinsed regularly with warm saline. Four weeks later normal microcirculatory patterns were found. The channels were patent and histology did not show necrosis or 
atrophy. It was possible to reconstruct the bowel strip along the long edge, like in the Monti tube. In this case the strip was kept less than $1 \mathrm{~cm}$ wide to get an ideally slim channel, however, spiral reconstruction allows cutting a wider $(1.5-2 \mathrm{~cm})$ strip with more sufficient blood supply.

In humans, catheters are usually left for a few weeks in Mitrofanoff channels and the patients self catheterise (dilate) them on regular basis afterwards to prevent stomal stricture at the skin level. The animals do not tolerate catheters sticking out of their body (we lost our catheters within days) and intermittent catheterisation of the channels is not possible without general anesthesia. In this study we did not expose the animals to this repeated stress. This is clearly a limitation of our model. This and the fact that pig skin is more robust than human may contributed to the stomal stenosis despite the use of V-shaped stomas in this study. However, we believe viability is the key to the reproducibility of easy catheterisation. The microcirculation data and the histology findings did not suggest chronic ischemia at skin level.

The Casale channels were reported requiring subfascial revision in $15.2 \%$ versus 8.3 $\%$ of the Monti channels (62). The nearly double complication rate may be related to the significant angulation in the middle of the Casale channel, which has to be straightened surgically during its creation. The possible tissue memory at this point, just like the anastomosis in double Monti channels may result in difficult catheter passage, stricture or perforation. The spiral channels were found to be straight. The suture line within the tube runs in spiral fashion, in theory it must guide the catheter tip easily, as the barrel of a rifle guides a bullet.

In conclusion, SILT technique is suitable on normal caliber bowel to create an alternative Mitrofanoff catheterisable stoma which is longer and straighter than can be achieved with present techniques.

This technique may have some potential for ureteral replacement as well. 


\subsection{Summary of the new results and conclusions}

1, Bladder exstrophy remains a major challenge that is best managed at dedicated centers. Failure of primary bladder closure, inadequate penile reconstruction in boys and unsuccessful bladder neck repair (BNR) represent the main obstacles to continence and spontaneous voiding. Even at the best centers results may be less than satisfactory and salvage continence surgery remains relevant. Bladder neck closure, bladder augmentation (BA) and continent cutaneous diversion ensure that the patient is dry. For those patients with a low leak pressure who tolerate urethral catheterization BA with BNR is a viable alternative. Cutaneous urinary diversion has a definite role in selected patients, particularly those who have undergone multiple operations previously or who do not accept CIC. Better patient selection coupled with concentration of resources and expertise at specialist exstrophy centers should allow more children to achieve continence following primary bladder surgery, thereby avoiding secondary salvage continence procedures.

2, Using state the orthogonal polarizing spectral imaging - state of the art intraoperative real time in vivo microscopy technique - we first provided direct evidence for safe and reliable antimesenteric and significant, but limited longitudinal intestinal intramural anastomoses in experimental settings.

3, Based on these observations, we modified conventional clam ileocystoplasty for cases when a short mesentery may compromise the success or safety of the procedure. With the paramesenteric detubularisation of the ileum we could achieve significantly longer reaching ileal flaps. This technique does not disturb the microcirculation of the ileal flap and it has been proven to be safe in our animal model. We demonstrated significant longitudinal intramural anastomoses in these flaps as well, but their efficacy was limited and seems not reliable for clinical application.

4, We demonstrated severely compromised microcirculation of the ileal flaps after experimental mucosectomy. The microcirculatory damage may be primarily responsible for flap contraction after bladder augmentation with mucosectomised intestinal flaps. This suggests that future research should focus on the preservation 
/restoration of the microcirculation during and after mucosectomy rather than reproducing urothelium coverage.

5, In an experimental model, we successfully applied the spiral intestinal lengthening and tailoring (SILT) technique on normal caliber bowel to create an alternative catheterisable cutaneous urinary diversion stoma, which is longer and straighter than can be achieved with the double Monti and the Casale techniques. This technique may have some potential for ureteral replacement as well. 


\section{LIST OF REFERENCE}

1, Adams MC and Joseph BD. Augmentation cystoplasty, Urinary tract reconstruction in children in Campbell-Wallsh Urology $10^{\text {th }}$ edition Esevier Philadelphia 2012; pp. 3672 .

2, Steinbrecher HA, Malone PS, Rickwood AMK. Surgery for impaired/high-pressure bladder capacity in Thomas DFM, Duffy GP, Rickwood AMK: Essential of paediatric urology Informa healthcare 2008, London, pp. 180.

3, Sigaroudinia MO, Baillie C, Ahmed S et al. Sclerosing encapsulating peritonitis--a rare complication of ventriculoperitoneal shunts. J Pediatr Surg 2008; 43: 31.

4, Arlen AM, Merriman LS, Elmore JM, Smith EA, Kirsch AJ. Rapid construction of sigmoid bladder augmentation using absorbable staples: longter $\mathrm{m}$ results and comparisonto standard colocystoplasty in children with neurogenic blad der. J Pediatr Urol. 2014;10: 284.

5, Levine LA: Stepladder incision technique for lengthening of bowel mesentery. J Urol 1992; 148: 351.

6, Baig MK, Weiss EG, Nogureas JJ et al. Lengthening of small bowel mesentery: stepladder incision technique. Am J Surg 2006; 191: 715.

7, Metcalf DR, Nivatvongs S, Sullivan TM et al. A technique of extending smallbowel mesentery for ileal pouch-anal anastomosis: report of a case. Dis Colon Rectum 2008; 51: 363.

8, Kropp BP, Cheng EY. Bladder augmentation: current and future techniques. In: Docimo SG, Canning DA, Khoury AE (editors). Clinical Pediatric Urology, London: Informa Healthcare; 2007. p.871-910.

9, Salle JL, Jednek R. Fibrosis of the sero-muscular segment. In: Dewan P, Mitchell ME (editors). Bladder augmentation, London: Arnold; 2000, p.80-81.

10, Shoemaker WC. Reversed sero-muscular grafts in urinary tract reconstruction. J Urol 1955; 74:453-75.

11, Shoemaker WC, Bower R, Long Dm Jr. A new technique for bladder reconstruction. Surg Gynecol Obstet 1957; 105:645-50.

12, Oesch I. Neourothelium in bladder augmentation. An experimental study in rats. Eur Urol 1988; 14:328-9. 
13, Salle JL, Fraga JC, Lucib A, Lampertz M, Jobim G, Jobim G, Putten A. Seromuscular enterocystoplasty in dogs. J Urol 1990; 144:454-6.

14, Motley RC, Montgomery BT, Kramer SA. Augmentation cystoplasty utilizing deepithelialized sigmoid colon: a preliminary study. J Urol 1990; 143:1257-60.

15, Salle JL, Homayoon K, Khoury AE. Determining factor in the contraction of deepithelialised gastric flap for bladder augmentation. J Urol 1997; 157:769A.

16, Turner A, Subramanian R, Thomas DF, Hinley J, Abbas SK, Stahlschmidt J, Southgate J. Transplantation of autologous differentiated urothelium in an experimental model of composite cystoplasty. Eur Urol 2011; 59:447-54.

17, Zhang Y, Liu G, Kropp BP. Re-epithelialization of demucosalized stomach patch with tissue-engineered urothelial mucosa combined with Botox A in bladder augmentation. BJU Int 2012; 110:106-12.

18, Hidas G, Lee HJ, Bahoric A, Kelly MS, Watts B,Liu Z, Saharti S, Lusch A, Alamsahebpour A, Kerbl D, Truong $\mathrm{H}, \mathrm{Zi} \mathrm{X}$, Khoury AE. Aerosol transfer of bladder urothelial and smooth muscle cells onto demucosalized colonic segments for bladder augmentation: In vivo, long term, and functional pilot study. J Pediatr Urol 2015; 11:260.e1-6.

19, Mitrofanoff P. Trans-appendicular continent cystostomy in the management of the neurogenic bladder. Chir Pediatr 1980; 21: 297.

20, Monti PR, Lara RC, Dutra MA and de Carvalho JR. New techniques for construction of efferent conduits based on the Mitrofanoff principle. Urology 1997; 49: 112 .

21, Casale AJ. A long continent ileovesicostomy using a single piece of bowel. J Urol 1999; 162: 1743.

22, Narayanaswamy B, Wilcox DT, Cuckow PM, Duffy PG and Ransley PG. The Yang Monti ileovesicostomy: a problem- atic channel? BJU Int 2001; 87: 861.

23, Michelis et al. Intestinal vascularization. J Int College of Surg 1963, 39:146.

24, Jonnesco T, Soulik A: In Poirier and Charpy's Traitg d'Anatomie Hurmaine, Vol. iv, Pt. i, 3rd ed. Paris: Masson et Cie 1912.

25, Eisberg H. B. Intestinal arteries. Anat Rec1924; 28: 227.6, Noer R. J: The blood vessels of the jejunum and ileum: a comparative study of man and certain laboratory animals. Amer J Anat 1943; 73: 293. 
26, Cokkinis AJ. Observations on the Mesenteric Circulation. J Anat 1930; 64:200-5.

27, Doran FS: Intramural blood supply of the upper jejunum in man. J Anat 1950; 84:283-6.

28, Grommes J, Binnebösel M, Klink CD, von Trotha KT, Schleimer K, Jacobs MJ, Neumann UP, Krones CJ. Comparison of intestinal microcirculation and wound healing in a rat model. J Invest Surg 2013; 26:46-52.

29, Turóczi Z, Fülöp A, Czigány Z, Varga G, Rosero O, Tökés T, Kaszaki J, Lotz G, Harsányi L, Szijártó A. Improvement of small intestinal microcirculation by postconditioning after lower limb ischemia. Microvasc Res 2015; 98C: 119-125.

30, De Backer D, Hollenberg S, Boerma C, et al. How to evaluate the microcirculation: report of a round table conference. Crit Care. 2007;11:R101

31, Eriksson S, Nilsson J, Sturesson C. Non-invasive imaging of microcirculation: a technology review Med Devices (Auckl) 2014; 7: 445-452.

32, Cerný V, Turek Z, Parízková R. Orthogonal polarization spectral imaging Physiol Res 2007; 56: 141-7.

33, https://en.wikipedia.org/wiki/Orthogonal_polarization_spectral_imaging

34, Vajda K, Szabó A, Kucsa K et al. Microcirculatory heterogeneity in the rat small intestine during compromised flow conditions. Microcirculation 2004; 11: 307.

35, Bajory Z, Szabó A, Deák G, Varga R, Pajor L. Orthogonal polarization spectral imaging: a novel tool for examination of microcirculatory changes in the testis. $\mathrm{J}$ Androl 2012;33:499-504

36, Bajory Z, Varga R, Janovszky Á, Pajor L, Szabó A. Microcirculatory effects of selective endothelin-A receptor antagonism in testicular torsion. J Urol $2014 ; 192$ : 1871-7.

37,https://www.jove.com/video/1035/murine-model-of-hindlimbischemia? iframe $=$ true \&width $=100 \%$ \&height $=100 \%$

38, https://www.youtube.com/watch?v=FB2WtQSF18Q

39, Cheng E, Rento R, Grayhack JT, Oyasu R, McVary KT. Reversed seromuscular flaps in the urinary tract in dogs. J Urol 1994; 152:2252-7.

40, Masuda T, Furue M, Matsuda T. Novel strategy for soft tissue augmentation based on transplantation of fragmented omentum and preadipocytes. Tissue Eng 2004; 10:1672-83. 
41, Xu L, Zhang S, Li J, Liu J, Huang W, Shang X. Human tracheal allotransplant with greater omentum for revascularization. Exp Clin Transplant 2014; 12:448-53.

42, Kainuma S, Miyagawa S, Fukushima S, Pearson J, Chen YC, Sawa Y. Cell-sheet therapy with omentopexy promotes arteriogenesis and improves coronary circulation physiology in failing heart. Mol Ther 2015; 23:374-86.

43, Baaj AA, Agazzi S, Sayed ZA, Toledo M, Spetzler RF, van Loveren H. Surgical management of moyamoya disease: a review. Neurosurg Focus 2009; 26:E7.

\section{4, Cserni T, Takayasu H, Muzsnay Z, Varga G, Murphy F, Folaranmi SE, Rakoczy}

G. New idea of intestinal lengthening and tailoring Pediatr Surg Int 2011 27:10091013.

45, Cserni T, Varga G, Erces D, Kaszaky J, Boros M, Morabito A, Takayasu H, Rakoczy G. Spiral Intestinal Lengthening and Tailoring- First in vivo study J Pediatr Surg 2013; 48:1907-1913.

46, Cserni T, Biszku B, Guthy I, Dicso F, Szaloki L, Folaranmi S, Murphy F, Rakoczy G, Bianchi A, Morabito A. The first Clinical Application of the Spiral Intestinal Lengthening and Tailoring (Silt) in Extreme Short Bowel Syndrome.J Gastrointest Surg. 2014; 18:1852-1857.

47, Meldrum KK, Baird AD and Gearhart JP: Pelvic and extremity immobilization after bladder exstrophy closure: complications and impact on success. Urology 2003; 62: 1109 .

48, Sponseller PD, Jani MM, Jeffs RD and Gearhart JP: Anterior innominate osteotomy in repair of bladder exstrophy. J Bone Joint Surg Am 2001; 83: 184.

49, Gearhart JP, Ben-Chaim J, Sciortino C, Sponseller PD and Jeffs RD: The multiple reoperative bladder exstrophy closure: what affects the potential of the bladder? Urology 1996; 47: 240.

50, Gearhart JP and Jeffs RD: Bladder exstrophy: increase in capacity following epispadias repair. J Urol 1989; 142: 525.

51, Neveus T, von Gontard A, Hoebeke P, Hjalmas K, Bauer S, Bower W et al: The standardization of terminology of lower urinary tract function in children and adolescents: report from the Standardisation Committee of the International Children's Continence Society. J Urol 2006; 176: 314.

52, Surer I, Baker LA, Jeffs RD and Gearhart JP: Modified Young-Dees Leadbetter bladder neck reconstruction in patients with successful primary bladder closure elsewhere: a single institution experience. J Urol 2001; 165: 2438.

53, Gearhart JP, Canning DA and Jeffs RD: Failed bladder neck reconstruction: options for management. J Urol 1991; 146:1082. 
54, Burki T, Hamid R, Duffy P, Ransley P, Wilcox D and Mushtaq I: Long-term followup of patients after redo bladder neck reconstruction for bladder exstrophy complex. J Urol 2006; 176: 1138.

55, Schroder A, Stein R and Thuroff J: High risk of malignancies and late complication in patients with bladder exstrophy following ureterosigmoidostomy. Presented at European Society of Paediatric Urology, Athens, Greece, April 26$29,2006$.

56, Bannister LH. Ileum in Alimentary system, Gray's Anatomy $38^{\text {th }}$ ed. 1995, Churchill Livingstone pp1765.

57, Noer RJ. The blood vessels of the jejunum and ileum: a comparative study of man and certain laboratory animals. Amer J Anat 1943; 73: 293.

58, Shoji H, Yamaguchi N, Isomoto H, Minami H, Matsushima K, Akazawa Y, Ohnita K, Takeshima F, Shikuwa S, Nakao K. Oral prednisolone and triamcinolone injection for gastric stricture after endoscopic submucosal dissection. Clin Endosc 2013; 46:472-475.

59, 47, Kwon YH, Jeon SW, Lee JK. Endoscopic management of refractory benign colorectal strictures. Ann Transl Med 2014; 22:2305-5839.

60, Dasgupta R, Langer JC. Transanal pull-through for Hirschsprung disease. Semin Pediatr Surg 2005; 14:64-71.

61, Kvietys PR. Extramural blood and lymphatic vessels. In: Kvietys PR (editor). Gastrointestinal Circulation. San Rafael: Morgan \& Claypool Life Sciences; 2010.

62, Leslie JA, Cain MP, Dussinger AM, Rink RC, Casale AJ. A comparison of the Monti and Casale (spiral Monti) procedures. J Urol 2007; 178: 1623-1627. 


\section{SUMMARY}

Despite the continuously improving surgical techniques the advanced medical technology severe congenital malformations like bladder exstrophy, cloacal exstrophy, posterior urethral valve and severe neurogenic bladder dysfunction in spinal dysraphism remain a major challenge in paediatric urology. In significant number of patients preservation of the kidney function and urinary continence is only possible with salvage procedures. The most common salvage procedures are the bladder augmentation with continent cutaneous diversion. These procedures are not perfect and still associated with severe surgical and medical complications.

This thesis is summarizing the author's clinical and experimental experience with bladder augmentation and cutaneous urinary diversions: I. assessing the clinical importance and efficacy of the procedures reviewing clinical data of patients after failed bladder exstropy repair, II. studying the intramural microcirculation of the ileum in animal model to III. provide experimental data for new surgical techniques may be used for safe bladder augmentation if mesentery short, furthermore IV. studying the effect of the mucosectomy on the ileal flaps used for "mucus free" bladder augmentation and V. proposes new alternative for longer and straighter catheterisable urinary cutaneous diversion.

I. In the first (clinical) study the data of 32 patients underwent salvage continence surgery after failed staged reconstruction for bladder exstrophy was reviewed. 29 of the 32 patients $(91 \%)$ become continent, $3(9 \%)$ remained intermittently and none continuously incontinent. 22 of the 32 patients $(68 \%)$ required bladder augmentation due to poor bladder capacity, 3 patients catheterising urethrally and in 19 of the 22 patients $(86 \%)$ continence was achieved after bladder neck closure, bladder augmentation and continent cutaneous diversion (Mitrofanoff) using clean intermittent catheterization. Four patients are continent after cutaneous urinary diversion alone. Bladder augmentation and cutaneous diversion play effective and significant role in the management of patients after failed exstrophy repair.

II. In the second study the intramural microcirculation of the ileum was studied in an animal model using intraoperative in vivo video microscopy based on Orthogonal 
Polarization Spectral Imaging (OPS). The presence and the efficacy of the antimesenteric and longitudinal intramural vascular anastomoses were assessed by paramesenteric detubularisation of the ileum and ligation of consecutive vasa recta in antimesenterically detubularised ileum. Significant and reliable antimesenteric and siginificant, but limited longitudinal anastomoses have been found within the wall of the ileum.

III. The results of the II. study suggest the ileum can be safely detubularised along a paramesenteric line, this could be used to achieve longer reaching ileal flap for bladder augmentation if mesentery short. In the III-rd study animal model was designed to test this hypothesis. Intraoperative OPS in vivo microscopy was used to demonstrate that paramesenteric detubularisation of the ileum results longer reaching flaps ( $+98 \%$ of the mean bowel width) for bladder augmentation and does not compromise the microcirculation. The flaps can be further lengthened with ligation of some vasa recta, but ligation of 2 vessels already results in significant drop in the velocity of the circulating red blood cells. Clam ileocystoplasty was performed in 5 pigs with paramesenterically detubularised ileum, all animals recovered, there was no urine leakage, suture break down, histology confirmed viable bowel flaps, no sign of atrophy or fibrosis was noted after 4 weeks. Paramesenteric detubularisation of the ileum is safe and results in longer reaching flap, this can be used if mesentery is short.

IV. Intestinal mucosa within the bladder is associated with high risk of urinary infection and stone formation (mucus production), metabolic problems (absorption of urinary electrolytes) and carcinogenesis. Bladder augmentation with demucosalised ileal flap is thought to be a promising approach for "mucosa free" bladder augmentation as ischemic effect of mucosectomy has not been proven. However, flap contraction still remains major concern. Extensive research is now focusing on to cover the raw surface of the ileal flaps after mucosectomy with urothelium believing the urine exposure to the raw surface might be responsible for flap contraction. However, the mucosectomy disrupting the intramural vascular circuits may have significant ischemic effect, which could be responsible for flap contraction alone. In the IV. study we measured the effect of the removal of mucosa/ submucosa on the microcirculation of the ileum flaps in pigs with intraoperative in vivo OPS. We found significant diminished microcirculation after mucosectomy in both groups. The 
paramesenteric detubularisation of the ileum allowed us to perform reverse flap clam ileocystoplasty (6 pigs) where the raw surface is not exposed to urine (serosa facing inside the bladder). We covered the raw surface (facing inside the abdomen) with omentum hoping it will help revascularise the flaps. No acute necrosis or perforation has been found, but significant contraction of ileal flaps seen after 8 weeks. This study showed that mucosectomy compromising microcirculation and may be responsible for flap contraction in augmented bladder.

$\mathrm{V}$. The occasional lack of appendix and the increasing use of the Malone Antegrade Continence Enema (MACE) procedure have expanded the need for alternative Mitrofanoff channels. The Monti procedure does not always provide adequate length, the anastomosis of the double Monti and the potential kink of the Casale channel is not ideal for smooth catheterisation. We tested the concept of spiral intestinal lengthening and tailoring (SILT), we developed originally for short bowel syndrome, to create a long and straight alternative Mitrofanoff channel in animal model (5 pig). The mean length of the spiral channel was longer than it could have been achieved with the double Monti or Casale procedure. Mild (up to $17 \%$ ) reduction was measured in the microcirculatory parameters at the edges of the bowel strip at the primary surgery. All implanted channels remained viable, straight, patent and easily catheterisable after 4 weeks. The histology showed no necrosis or fibrosis.

It has been proved the SILT concept is suitable for creating a long and straight alternative Mitrofanoff channel. 


\section{MAGYAR NYELVÜ ÖSSZEFOGLALÁS}

\section{Bevezetés}

Súlyos fejlődési rendellenességek, mint pl. a hólyag exstrophia, cloacalis exstrophia és a nyitott gerincvelővel született gyermekek súlyos neurogen hólyagja még mindíg nagy kihívást jelent a gyermekurológiában. Az anatómiai reconstrukció mellett az ún. „mentőmegoldásoknak”, amelyek például a hólyag vizelet tároló kapacitását növelik (hólyag augmentáció) és a kontinenciát és a viezeleürítést biztosítják (kontinens katéterezhető stomáknak) még mindíg szignifikáns jelentőségük van a betegek kezelésében.

Jelenleg az ileocystoplastica Mitrofanoff katéterezhető stomaval a leginkább elfogadott „mentőmegoldás” gyermekkorban, annak ellenére, hogy ez az eljárás még számos megoldatlan problémát jelent betegeinknek. Ilyen például az augmentált hólyagban a bélnyálkahártya által termelt nyálka, ami a húgyúti fertőzések gyakoriságát és a kőképződést növeli. A bélnyálkahártyán keresztül, a vizeletből felszívódó elektrolitok okozta súlyos metabolikus problémák és a bélnyálkahártya malignus elváltozása szintén nagyon gyakori. Maga az augmentáció kivitelezése is problémás lehet olyan gyermekeknél, ahol a mesenterium megrövidül pl. ventriculoperitonealis shunttel élö gyermekek.

A gyermekurológusok régi álma kirekeszteni a bélnyálkahártyát az augmentált hólyagból. Az ún. sero-muscularis és sero-musculo-submucosalis lebenyek használata augmentáció céljából nagyon vonzó, de a lebenyek zsugorodása még mindig nagy probléma. Széleskörü és drága kutatás öszpontosít arra, hogy a mucosa eltávolítása után a lebenyekre urotheliumot telepítsenek, megvédjék a lebenyt a vizelettől, ami egyes elképzelések szerint a lebenyek kontrakciójáért felelös. Ugyanakkor már önmagában a mucosa eltávolítása, az intramuralis vascularis plexusok roncsolása és az így okozott ischemia is felelös lehet a lebenyek zsugorodásáért. Ezt azonban senki nem tudta bizonyítani.

Az ileocystoplastica során az ileumot tradícionálisan az antimesenterialis vonal mentén detubularizálják, ugyanakkor ha a paramesenterialis vonal mentén detubularizálunk, az ileum lebeny mélyebbre ér le a kismedencébe és ez előnyösebb lehet olyan esetben, amikor a mesenterium rövid és az augmentáció nehéz. Egy-egy mesenteriális Vasa recta lekötése, esetleg a két megoldás kombinálása könnyebbé és 
biztonságosabbá tenné az augmentációt, feszülés nélküli anasztomozist biztosítva, de erre vonatkozó adat nem található az irodalomban.

Katéterezhető stoma céljából leggyakrabban az appendix vermiformist használjuk, de ha az hiányzik, vagy nem megfelelő a vékonybélből Monti cső készíthető. Bizonyos esetekben, kerekes székben ülö, obez gyermekeknél a hasfal vastagsága miatt a Monti cső nem elég hosszú. Ilyen esetekben dupla Monti, vagy Casale csövet kell készíteni, azonban ezek a csövek nem ideálisak, mert könnyebben megtörnek és elzáródhatnak.

\section{Célkitűzés}

A szerző célja az első lépésben az volt, hogy klinikai adatok alapján elemezze a hólyag augmentáció és katéterezhető stoma fontosságát és hatékonyságát, sikertelen, azaz kontinenciát nem biztosító primer mütéti rekonstrukció után, hólyag exstrophiás betegekben. A további cél a hólyagaugmentációhoz és katéterezhető stomakhoz használt vékonybél lebenyek mikrokeringésének vizsgálata volt in vivo mikroszkópia, ortogonális polarizációs spektrális (OPS) képalkotás segitségével. Kíváncsiak voltunk az ileum intramuralis vascularis anasztomozisainak hatékonyságára azért, hogy biztonságos augmentációt készíthessünk akkor is, ha a mesenterium rövid. Meg akartuk ismerni a mucosa eltávolításának a mikrokeringésre gyakorolt hatását azért, hogy megértsük van-e ennek szerepe a lebenyek zsugorodásában. Továbbá a bél mikrokeringésének ismeretében hosszabb és egyenesebb, megtöretésre nem hajlamos katéterezhető stoma készítsének lehetőségét kerestük.

\section{Anyag és módszer}

\section{Betegek és módszer:}

A manchesteri exstrophia centrumban kezelt 32 sikeretelen primer exstrophia rekonstrukción átesett beteg adatait elemeztük. 11 beteg primer rekonstrukciója a manchesteri intézetben történt, 22 beteget más intézet referált. Azok a gyermekek akik 5 éves korban még mindíg inkontinensek voltak kontinencia javító mütére kerültek. Azoknál, akiknél a hólyag kapacitás $85 \mathrm{~cm}^{3}$-nél nagyobb volt és a felső traktus egészséges maradt módosított Young-Dees hólyagnyak rekonstrukciót végeztünk. Azok, akik a mütét után nem voltak képesek spontán üríteni a hólyagjukat intermittáló katéterezést (CIC) kezdtek, vagy katéretezhető stomat kaptak hólyag augmentációval vagy anélkül, a hólyag kapacitásától függően. Azok, akik 
inkontinensek maradtak hólyagnyak zárásra kerültek, augmentáció és stoma készítése mellett. Azoknál, akiknél a hólyag kapacitása nem érte el a $85 \mathrm{~cm}^{3}$-t hólyagaugmentációt, hólyagnyak zárást végeztünk katéterezhető stomával. A kontinencia az International Children's Continence Society által meghatározott terminológia alapján (kontinens, intermittálóan continens és folyamatosan inkontinens) került meghatározásra.

\section{Kisérleti állatok, müszerek:}

A kísérleteket során vietnámi törpesertéseket használtunk. In vivo mikroszkóp (Cytoscan A/R, Cytometrics, PA, USA) segítségével a mikrokeringés két legfontosabb mérhető paraméterét a cirkuláló vörös vértestek (vvt) sebességét és a nyitott illetve zárt kapillárisok arányát (perfúziós ráta) határoztuk meg.

\section{Az antimesenterialis intramuralis vascularis anasztomozisok vizsgálata:}

10 cm-es jejunum kacsokat izoláltunk. A kontrol csoportban antimesenterialisan, míg a az I. csoportban a mesenterialis és az antimesenterialis vonal között középen, majd a II. csoportban paramesenterialisan detubularizáltuk a belet. A mikrokeringést a kiterített lebenyek szélén mértük az antimesenterialis vonalon túl a nyálkahártyán.

\section{A longitudinalis intramuralis vascularis anasztomozisok vizsgálata:}

A mucosa mikrokeringését először a vékonybéltől nem izolált, antimesenteriálisan felnyitott bélszakaszon vizsgáltuk 2,4,6 mesenterialis ér lekötését követően. Majd ezt a vizsgálatot izolált vékonybél szabad végén is megismételtük.

\section{A mucosa eltávolításának a mikrokeringésre gyakorolt hatása}

A egyik csoportban csak a mucosat távolítottuk el a vékonybélről, a másik csoportban a mucosat és a submucosat is lepreparáltuk. A beavatkozások után megmértük a béllebenyek szélességét és rögzítettük a mikrokeringési adatokat a serosa felöl. Majd a lebenyekkel reverse „clam” ileocystoplasticat végeztünk (a bél serosaja néz a hólyag belseje felé). A mucosa-fosztott felsznít pedig omentummal fedtük. Az állatokat $(n=6) 8$ hét múlva elaltattuk és az augmentált hólyagot eltávolítottuk, a lebenyek szélességét megmértük.

\section{Új augmentációs eljárás rövid mesenterium esetére:}

A paramesenterialisan detubularizált vékonybél lebenyeket kiterítettük és a lebeny szélétől számított mesenteriális Vasa rectakat egyesével, egymás után lekötöttük, közben mértük, hogy a lebeny milyen messzire ér az egyes erek lekötése után és rögzítettük a lebeny széleinek mikrokeringési adatait. Majd clam ileocystoplasticat végeztünk paramesenterialisan detubularisált ileummal. Az állatokat 4 hét után újból 
elaltattuk és az augmentált hólyagokat eltávolítottuk és konvencionális szövettani vizsgálatot végeztünk.

\section{Hosszú és egyenes katéterezhető stoma új koncepciója:}

Clam ileocystoplastica során egy a vékonybél 6-8 cm hosszú újabb szakaszát spirál alakban vágtuk fel úgy, hogy a középen erös mesenterialis vérelláltása maradjon. Az így kapott bélcsík mikrokeringését megmértük a csík mindkét végén és a közepén. Majd a belet spirál alakban újból egy hosszabb, de vékonyabb csővé rekonstruáltuk (12 F -es katéter felett) és katéterezhető stomaként a hólyagba implantáltuk, illetve a hasfalon áthúzva a bőrhöz kiöltöttük. Az állatokat 4 hét múlva feláldoztuk és megvizsgáltuk a katéterezhető csatornákat életképessét, átjárhatóságát, illetve konvencionális szövettani vizsgálatot végeztünk.

Statisztikai analízisseket SigmaStat for Windows (Jandel Scientific, Germany) programcsomag segítségével végeztük.

\section{Föbb eredmények összefoglalása}

1, A 32 betegből 29-nél (91\%) sikerült kontinenciát elérni, 3 gyermek (9\%) maradt intermittálóan inkontinens. Hólyag augmentációra 22 gyermeknél (68\%) volt szükség. Három beteg katéterezik urethralisan. A 22-ből 19 gyermeknél (86\%) a kontinencia elérése céljából a hólyagnyakat zárni kellett és katéterezhető stoma is készült. Összesen 4 beteg kontinens egyedül katéterezhető stoma készítése után. Hólyag augmentáció és katéterezhető stoma nélkülözhetetlen a betegek kezelésében ha a primer rekonstrukció nem vezet kellő eredményre.

2, Modern technika alkalmazásával (real-time in vivo mikroszkópia, OPS) először sikerült direkt bizonyítékkal szolgálni arra, hogy megbízható és hatékony antimesenterialis anasztomózisok léteznek a bél falában. Ugyanakkor a longitudinális irányú kapcsolat a erek között limitált, nem megbízható.

3, Ezekre a mérésekre alapozva módosítottuk a megszokott clam ileocystoplasticat olyan esetekre amikor a rövid mesenterium miatt az ileocystoplastica nem lenne biztonságosan kivitelezhető. A paramesenterialisan detubularizált ileummal szignifikánsan hosszabb, a medencébe érő lebenyeket készítettünk. Méréseink szerint ez a megoldás nem kompromittálja a vékonybél lebeny mikrokeringését, és a mütét biztonságosnak mutatkozott az állatmodellben is. Ezekben a paramesenterialisan 
detubularizált lebenyekben is demonstráltuk a longitudinális intramurális anasztomózisokat jelenlétét, de ezek hatékonyága korlátozottnak mutatkozott és klinikai felhasználásuk nem tünik megbízhatónak.

4, Méréseinkkel egyértelmúen demonstráltuk a vékonybél lebenyek mikrokeringésének zavarát a bélnyálkahártya sebészi eltávolítása után. A mikrokeringésben észlelt zavar elsődlegesen lehet felelős a lebenyek későbbi zsugorodásáért az augmentált hólyagban. A jövőben a kutatásokat a érdemes lenne a mikrokeringés megőrzésére / helyreállítására-ra is fókuszálni az urothelium reprodukálása elött.

5, A kísérleti állatmodellben sikerrel alkalmaztuk a spiralis intestinal lengthening and tailoring (SILT) koncepcióját nem tágult bélen, és a dupla Monti és Casale stomaknál hosszabb és egyenesebb életképes katéterezhető csatornát sikerült készíteni. 


\section{AKNOWLEDGEMENT}

I would like to express my deep and sincere gratitude to my tutor and supervisor Mr. Tamas Cserni PhD, Med.Habil guiding me the whole program, for organising my operative experimental work, reviewing my manuscripts.

Special thanks for Professor Mihály Boros, Director of the Department of Operative Techniques and Surgical Research, University of Szeged for supporting my work and providing the facilities at the institution.

I owe to Mr József Kaszaki Associate Professor of the Department of Operative Techniques and Surgical Research thanks for organising my operative experimental work, reviewing my manuscripts and helping in statistics.

Thanks to Ms Gabriella Varga PhD, Dr. Dániel Hajnal fellow researchers for recording and analysing of the OPS images and performing statistical analysis, to Mr Dániel Érces $P h D$ for the veterinary care and the co-workers of the Institute of Surgical Research for the practical advices and help during the experiments.

I would like to express my thanks and gratitude to all my friends and colleagues who helped me in various stages of this project.

Special thanks to my family for their patience and support to finish this project successfully. 
10. APPENDIX 